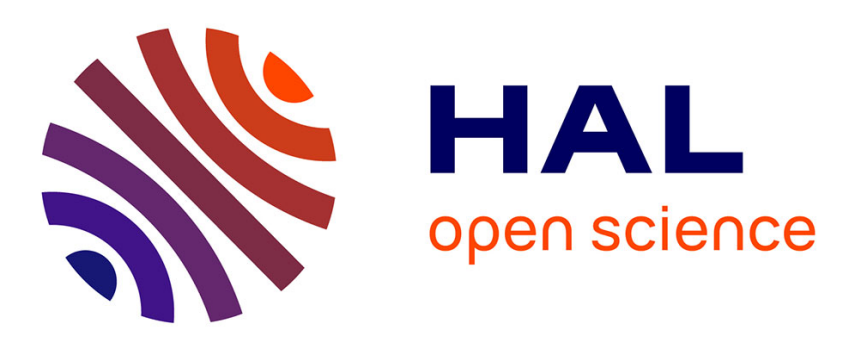

\title{
Molecular tectonics: dimensionality and geometry control of silver coordination networks based on pyrazolyl appended thiacalixarenes
}

Alexander Ovsyannikov, Mohamed Noamane, Rym Abidi, Sylvie Ferlay, Svetlana Solovieva, Igor Antipin, A. Konovalov, Nathalie Kyritsakas, Mir Wais Hosseini

\section{To cite this version:}

Alexander Ovsyannikov, Mohamed Noamane, Rym Abidi, Sylvie Ferlay, Svetlana Solovieva, et al.. Molecular tectonics: dimensionality and geometry control of silver coordination networks based on pyrazolyl appended thiacalixarenes. CrystEngComm, 2016, 18 (5), pp.691-703. 10.1039/C5CE02310F . hal-02301062

\section{HAL Id: hal-02301062 https://hal.science/hal-02301062}

Submitted on 25 Nov 2020

HAL is a multi-disciplinary open access archive for the deposit and dissemination of scientific research documents, whether they are published or not. The documents may come from teaching and research institutions in France or abroad, or from public or private research centers.
L'archive ouverte pluridisciplinaire HAL, est destinée au dépôt et à la diffusion de documents scientifiques de niveau recherche, publiés ou non, émanant des établissements d'enseignement et de recherche français ou étrangers, des laboratoires publics ou privés. 


\section{ARTICLE}

hCite this: DOI: 10.1039/x0xx00000x

\section{Molecular tectonics: dimensionality and geometry control of silver coordination networks based on pyrazolyl appended thiacalixarenes}

Received 00th January 2012,

Accepted 00th January 2012

DOI: 10.1039/x0xx00000x

www.rsc.org/

\author{
A.S. Ovsyannikov, ${ }^{\mathrm{a}, \mathrm{b}, \mathrm{c}}$ M. H. Noamane, ${ }^{\mathrm{b}, \mathrm{d}}$, R. Abidi, ${ }^{\mathrm{d}}$ S. Ferlay, ${ }^{* \mathrm{~b}}$ S. E. Solovieva, ${ }^{\mathrm{a}, \mathrm{c}}$ I. \\ S. Antipin, ${ }^{\mathrm{a}, \mathrm{c}}$ A. I. Konovalov, ${ }^{\mathrm{a}, \mathrm{c}}$ N. Kyritsakas, ${ }^{\mathrm{b}}$ M. W. Hosseini ${ }^{* b}$
}

Combinations of six new coordinating tectons (3-8) tetrakis-pyrazolyl appended calix[4]arenes, blocked in 1,3-A conformation, based on $\mathbf{1}$ (tetrathiacalix[4]arene) and $\mathbf{2}$ (tetrathiatetramercaptocalix[4]arene) derivatives, with $\mathrm{AgX}$ salts $\left(\mathrm{X}=\mathrm{NO}_{3}^{-}, \mathrm{BF}_{4}^{-}, \mathrm{XF}_{6}^{-}(\mathrm{X}=\mathrm{P}, \mathrm{As}\right.$ and $\mathrm{Sb}$ )) lead to nine new silver coordination networks. The flexible nature of tectons 3-8 (length of the spacer between the macrocycle and the pyrazolyl coordinating unit), their high number of potential coordinating sites and the loose coordination demand of $\mathrm{Ag}^{+}$cation lead to the formation of a large variety of networks with different dimensionality: from $1 \mathrm{D}\left(\mathbf{5}-\mathrm{AgSbF}_{6}, \mathbf{5}-\mathrm{AgBF}_{4}, 7-\right.$ $\mathrm{AgSbF}_{6}$ and $\left.8-\mathrm{AgNO}_{3}\right)$ to extended $2 \mathrm{D}\left(\mathbf{6}-\mathrm{AgBF}_{4}\right.$ and $\left.\mathbf{8}-\mathrm{AgSbF}_{6}\right)$ and to a series of three isostructural porous diamond-like $3 \mathrm{D}$ architectures $\left(6-\mathrm{AgXF}_{6}(\mathrm{X}=\mathrm{P}\right.$, As and $\left.\mathrm{Sb})\right)$.

\section{Introduction}

The design of crystals and development of crystal synthesis are challenging issues of current interest. These two aspects have been subjects of crystal engineering, ${ }^{1}$ a research area at the frontier between solid state and supramolecular chemistry. ${ }^{2}$ Indeed, as stated by J. Dunitz, crystals, extended periodic assemblies, may be considered as supermolecules ${ }^{3}$ for which the components are assembled by attractive intermolecular interactions. However, owing to the complexity of molecular crystal generation, except for some specific combinations of molecular components, the prediction of crystal structure remains in general illusory. Molecular tectonics is an alternative solution to crystal synthesis. ${ }^{4}$ However, this approach is more restrictive since its aim is to design and generate molecular networks, periodic molecular architecture, in the crystalline phase. ${ }^{5,6}$ In other terms, molecular tectonics is not concerned with crystal structure prediction but with the control, under self-assembly conditions, of connectivity between informed and programmed molecular building blocks or tectons through iterative molecular recognition processes. ${ }^{4,7}$
Among many possible intermolecular or ion-molecule interactions that can be employed for the design of molecular networks, coordination bonds have been extensively used to generate a subclass of molecular networks called coordination polymers, ${ }^{8}$ coordination networks ${ }^{9}$ or metal organic frameworks. ${ }^{10}$ Since $c a$ two and half decades, this class of crystalline materials has been attracting considerable interest and continue to do that. ${ }^{11}$ Coordination networks are extended periodic architectures combining organic coordinating tectons and metal centres or metal complexes as metallatectons.

For the design of coordinating tectons, calix[4]arene (CA) ${ }^{12}$ and its sulphur analogue tetrathiacalix[4]arene TCA, ${ }^{13}$ (compound 1, Figure 1) and tetramercaptocalix[4]arene ${ }^{14,15}$ and tetramercaptotetrathiacalix[4]arene TMTCA (compound 2, Figure 1$)^{16,17}$ are interesting macrocyclic backbones. Both molecules are not planar but adopt four interconvertible limit conformations (cone, partial cone, 1,2-alternate and 1,3alternate). Whereas the cone conformer may be used for the generation of discrete assemblies, ${ }^{18,19,20}$ all other three conformer (partial cone, 1,2-alternate and 1,3-alternate) may be used as coordinating tectons for the formation of extended coordination networks. Periodic infinite 1-, 2- and 3-D silver 
coordination networks based on thiacalix[4]arene derivatives in 1,3-alternate conformation bearing four nitrile groups, ${ }^{21}$ carboxylate units ${ }^{22}$ or benzonitrile groups ${ }^{23}$ have been described. Another type of 1D silver network based on a TCA derivative, bearing ether junctions, has been also reported. ${ }^{24}$ The formation of $\mathrm{Cu}(\mathrm{I})$ coordination networks based on TCA has been described. ${ }^{25}$ Infinite architectures based on combinations of TCA derivatives bearing carboxylate groups with metal cations and auxiliary ligands have been also described. ${ }^{26}$

The coordination ability of TMTCA has been studied and few discrete complexes ${ }^{27}$ as well as examples of $\mathrm{Hg}$ (II), $\mathrm{Fe}$ (II), Cd (II) or $\mathrm{Ag}(\mathrm{I})$ coordination networks based on pyridyl appended TMTCA derivatives in 1,3-alternate conformation have been reported. $28,29,30$

As stated above, although molecular tectonics focuses on the design and synthesis of molecular networks in the crystalline phase, as for crystal engineering, except for combinations of rigid complementary tectons (restricted conformational space) with well defined recognition events between them, for flexible tectons offering a large conformational space and different possible recognition modes, the prediction of the connectivity and geometry of networks remains impossible. However, one may discover the formation of periodic extended architectures through systematic experimental explorations based on variations of tectons flexibility and binding ability. In particular, for coordination networks, one may design a series of structurally related coordinating tectons and investigate their combinations with metal connectors.

Here, we report on combinations of a series of 6 new neutral tetrapyrazolyl appended tectons 3-8 based on thiacalixarene TCA (3-5) and tetramercaptothiacalixarene TMTCA (6-8) backbones in 1,3-A conformation (Figure 1) with different silver salts.
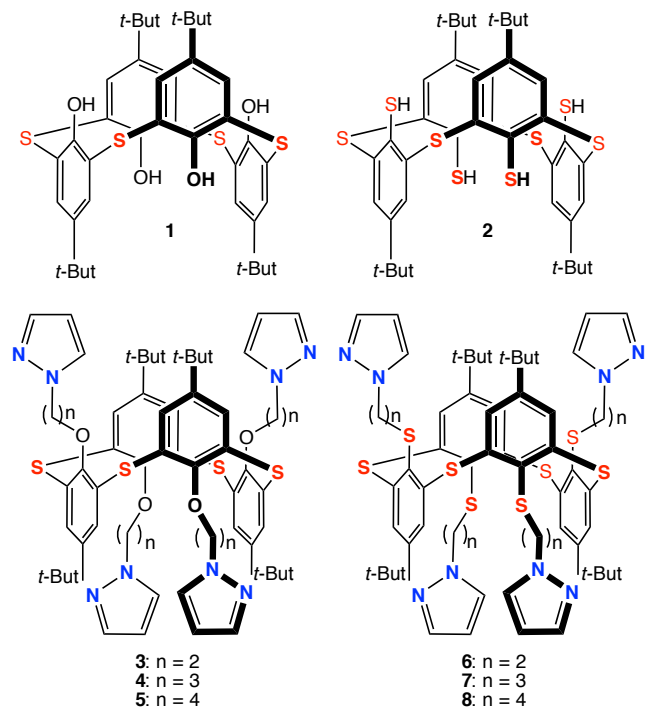

Figure 1: TCA 1 and TMTCA 2 in 1,3-A conformation as well as pyrazolyl appended tectons $\mathbf{3 - 8}$.

\section{Experimental section}

\section{Characterization techniques}

${ }^{1} \mathrm{H}-\mathrm{NMR}$ and ${ }^{13} \mathrm{C}-\mathrm{NMR}$ spectra were recorded at room temperature on a Bruker $300 \mathrm{MHz}$ and $500 \mathrm{MHz}$ spectrometers by the shared NMR Service.

FT-IR spectra were recorded on a Perkin Elmer ATR spectrometer.

Mass spectra (MS (ES+)) were obtained on a Bruker MicroTOF spectrometer by the shared Mass Spectrometry Service.

Melting points were measured in capillary on a Stuart Scientific Melting Point SMP-1 apparatus.

Microanalyses were performed by the shared Elemental Analysis Service.

\section{Synthesis}

General: All reagents were purchased from commercial sources and used without further purification. p-tertbutylthiacalix[4]arene (TCA) $\quad \mathbf{1}^{31}$ and p-tertbutyltetramercaptothiacalix[4]arene (TMTCA) $2^{16}$ were prepared following reported procedures.

\section{1-(2-bromoethyl)-1H-pyrazole ${ }^{32}$}

To a stirred solution of pyrazole $(0.5 \mathrm{~g}, 7.3 \mathrm{mmol})$ in DMSO $(50 \mathrm{~mL}) \mathrm{KOH}(4.12 \mathrm{~g}, 73 \mathrm{mmol})$ was added at room temperature. After stirring for $1 \mathrm{~h}, 1,2$-dibromoethane $(12.7 \mathrm{~mL}$, $146 \mathrm{mmol}$ ) was added and the mixture stirred for 2 hours before water $(50 \mathrm{~mL})$ was added. The mixture was extracted with EtOAc $(50 \mathrm{~mL})$ and $\mathrm{CH}_{2} \mathrm{Cl}_{2}(50 \mathrm{~mL})$. The combined organic layers were washed with brine $(100 \mathrm{~mL})$ and dried over anhydrous $\mathrm{MgSO}_{4}$, filtered and volatiles were evaporated. The liquid residue thus obtained was purified by flash column chromatography on $\mathrm{SiO}_{2}$ (cyclohexane/EtOAc 1/1 mixture) affording the pure 1-(2-bromoethyl)-1H-pyrazole $(0.77 \mathrm{~g})$ in $60 \%$ yield. ${ }^{1} \mathrm{H}-\mathrm{NMR} \delta\left(\mathrm{CDCl}_{3}, 300 \mathrm{MHz}\right): 3.72(2 \mathrm{H}, \mathrm{t}, \mathrm{Br}-$ $\left.\mathrm{CH}_{2}-\right), 4.50\left(2 \mathrm{H}, \mathrm{t},-\mathrm{CH}_{2}-\mathrm{Pyr}\right), 6.26(1 \mathrm{H}, \mathrm{t}, \mathrm{Pyr}-H), 7.46(1 \mathrm{H}, \mathrm{d}$, Pyr- $H), 7.55(1 \mathrm{H}, \mathrm{d}, \mathrm{Pyr}-H)$.

\section{1-(4-bromobutyl)-1H-pyrazole}

To a stirred solution of pyrazole $(0.5 \mathrm{~g}, 7.3 \mathrm{mmol})$ in DMSO $(50 \mathrm{~mL}) \mathrm{KOH}(4.12 \mathrm{~g}, 73 \mathrm{mmol})$ was added at room temperature. After stirring for $1 \mathrm{~h}, 1,4$-dibromobutane $(31.82 \mathrm{~g}$, $17.6 \mathrm{~mL}, 146 \mathrm{mmol}$ ) was added in one portion and the mixture further stirred for 2 hours. To the reaction mixture water (50 $\mathrm{mL}$ ) was added and the desired product was extracted with EtOAc $(50 \mathrm{~mL})$ and $\mathrm{CH}_{2} \mathrm{Cl}_{2}(50 \mathrm{~mL})$. The combined organic layers were washed with brine $(100 \mathrm{~mL})$ and dried over anhydrous $\mathrm{MgSO}_{4}$, filtered and the evaporated under vacuum. The liquid residue thus obtained was purified by flash column chromatography on $\mathrm{Al}_{2} \mathrm{O}_{3}$ (cyclohexane/EtOAc 1/1 mixture) affording the pure 1-(4-bromobutyl)- $1 H$-pyrazole $(0.97 \mathrm{~g})$ in $65 \%$ yield. ${ }^{1} \mathrm{H}-\mathrm{NMR} \delta\left(\mathrm{CDCl}_{3}, 300 \mathrm{MHz}\right): 1.84(2 \mathrm{H}, \mathrm{m}, \mathrm{Br}-$ $\left.\mathrm{CH}_{2}-\mathrm{CH}_{2}-\right), 2.02\left(2 \mathrm{H}, \mathrm{m},-\mathrm{CH}_{2}-\mathrm{CH}_{2}-\mathrm{Pyr}\right), 3.39\left(2 \mathrm{H}, \mathrm{t}, \mathrm{Br}-\mathrm{CH}_{2}-\right)$, $4.18\left(2 \mathrm{H}, \mathrm{t},-\mathrm{CH}_{2}-\mathrm{Pyr}\right), 6.24(1 \mathrm{H}, \mathrm{t}, \mathrm{Pyr}-H), 7.37(1 \mathrm{H}, \mathrm{d}, \mathrm{Pyr}-H)$, $7.50(1 \mathrm{H}, \mathrm{d}, \mathrm{Pyr}-H)$. 
25,26,27,28-tetrakis [(3-bromoethyl)]-5,11,17,23-tetra-tertbutyl-2,8,14,20-thiacalix[4] arene (3') (see figure 2$)^{33}$

Under argon, a mixture of TCA $1(2.0 \mathrm{~g}, 2.77 \mathrm{mmol})$ and $\mathrm{PPh}_{3}$ $(7.27 \mathrm{~g}, 27.73 \mathrm{mmol})$ in dry THF $(20 \mathrm{~mL})$ was stirred at $0{ }^{\circ} \mathrm{C}$ for $20 \mathrm{mn}$. Then, 2-bromoethanol $(3.64 \mathrm{~g}, 2.06 \mathrm{~mL}, 27.73$ $\mathrm{mmol}$ ) in dry $10 \mathrm{~mL}$ of THF was added dropwise. After stirring for $30 \mathrm{mn}$, a solution of DIAD (Diisopropyl Azodicarboxylate) $(5.72 \mathrm{~g}, 5.57 \mathrm{~mL}, 27.73 \mathrm{mmol})$ in dry THF $(10 \mathrm{~mL})$ was added dropwise. The reaction mixture was stirred under argon, at room temperature, during 24 hours before it was it evaporated to dryness. The residue was treated with $\mathrm{MeOH}(100 \mathrm{ml})$ affording the desired compound $\mathbf{3}^{\prime}$ in $1,3-A$ conformation as a white powder $(2.8 \mathrm{~g}, 89 \%$ yield $) . \mathrm{mp}=>320{ }^{\circ} \mathrm{C} .{ }^{1} \mathrm{H}-\mathrm{NMR}$ $\left(\mathrm{CDCl}_{3}, 500 \mathrm{MHz}\right) \delta(\mathrm{ppm})=1.31\left(36 \mathrm{H}, \mathrm{s}, \mathrm{C}\left(\mathrm{CH}_{3}\right)_{3}\right), 2.56(8 \mathrm{H}$, $\left.\mathrm{t}, \mathrm{Br}-\mathrm{CH}_{2}-\right), 4.11\left(8 \mathrm{H}, \mathrm{t},-\mathrm{CH}_{2}-\mathrm{O}-\right), 7.36(8 \mathrm{H}, \mathrm{s}, \mathrm{Ar}-H) .{ }^{13} \mathrm{C}-$ $\mathrm{NMR}\left(\mathrm{CDCl}_{3}, 125 \mathrm{MHz}\right) \delta(\mathrm{ppm})=31.6,34.7,67.3,127.4$, $128.1,147.5,153.4$.

\section{5,26,27,28-tetrakis [(3-bromopropyl)]-5,11,17,23-tetra-tert-} butyl-2,8,14,20-thiacalix[4] arene(4')

Under argon, a mixture of TCA $1(1.0 \mathrm{~g}, 1.38 \mathrm{mmol})$ and $\mathrm{PPh}_{3}$ (3.67 $\mathrm{g}, 13.86 \mathrm{mmol})$ in dry THF $(20 \mathrm{~mL})$ was stirred at $0{ }^{\circ} \mathrm{C}$. Then 3-bromo-1-propanol (1.98 g, $1.29 \mathrm{~mL}, 13.86 \mathrm{mmol})$ in dry THF $(10 \mathrm{~mL})$ was added dropwise to the mixture. After further stirring for $30 \mathrm{mn}$, a solution of DIAD (Diisopropyl Azodicarboxylate) $(2.85 \mathrm{~g}, 2.78 \mathrm{~mL}, 13.86 \mathrm{mmol})$ in dry THF $(10 \mathrm{~mL})$ was added dropwise. The reaction mixture was stirred for 24 hours at room temperature under argon before it was evaporated. The residue was treated with $\mathrm{MeOH}(100 \mathrm{ml})$ affording the desired compound 4' in 1,3-A conformation as a white powder, $(1.67 \mathrm{~g}, 91 \%$ yield $) . \mathrm{mp}>320{ }^{\circ} \mathrm{C} .{ }^{1} \mathrm{H}-\mathrm{NMR}$ $\left(\mathrm{CDCl}_{3}, 500 \mathrm{MHz}\right) \delta(\mathrm{ppm})=1.32\left(36 \mathrm{H}, \mathrm{s}, \mathrm{C}\left(\mathrm{CH}_{3}\right)_{3}\right), 1.55(8 \mathrm{H}$, m, $\left.-\mathrm{CH}_{2-}\right), 3.07$ (8H, t, Br- $\left.\mathrm{CH}_{2}-\mathrm{CH}_{2}-\right), 3.98$ (8H, t, $\left.-\mathrm{CH}_{2}-\mathrm{O}-\right)$, $7.37(8 \mathrm{H}, \mathrm{s}, \mathrm{Ar}-H) .{ }^{13} \mathrm{C}-\mathrm{NMR}\left(\mathrm{CDCl}_{3}, 125 \mathrm{MHz}\right) \delta(\mathrm{ppm})=$ $30.5,31.4,32.2,34.5,67,127.2,128.1,146.5,156.3$.

\section{5,26,27,28-tetrakis [(3-chlorobutyl)]-5,11,17,23-tetra-tert- butyl-2,8,14,20-thiacalix [4] arene (5')}

Under argon, a mixture of TCA $1(1.0 \mathrm{~g}, 1.38 \mathrm{mmol})$ and $\mathrm{PPh}_{3}$ (4.40 g, $16.64 \mathrm{mmol})$ in dry THF $(20 \mathrm{~mL})$ was stirred at $0{ }^{\circ} \mathrm{C}$. Then 4-chloro-1-butanol (2.12 g, $1.95 \mathrm{~mL}, 16.64 \mathrm{mmol})$ in dry THF $(10 \mathrm{~mL})$ was added dropwise. After stirring for $30 \mathrm{mn}$, a solution of DIAD (Diisopropyl Azodicarboxylate) (3.39 g, 3.30 $\mathrm{mL}, 16.64 \mathrm{mmol})$ in dry THF $(10 \mathrm{~mL})$ was added dropwise. The reaction mixture was stirred at room temperature for 24 hours under argon before it was evaporated. The residue was treated with $\mathrm{MeOH}(100 \mathrm{ml})$ affording the desired compound 5' in $1,3-A$ conformation as a white powder (1.31 g, $88 \%$ yield). $\mathrm{mp}>320{ }^{\circ} \mathrm{C} .{ }^{1} \mathrm{H}-\mathrm{NMR}\left(\mathrm{CDCl}_{3}, 300 \mathrm{MHz}\right) \delta(\mathrm{ppm})=1.19$ $\left(36 \mathrm{H}, \mathrm{s}, \mathrm{C}\left(\mathrm{CH}_{3}\right)_{3}\right), 1.19\left(8 \mathrm{H}, \mathrm{m},-\mathrm{CH}_{2}-\right), 1.50\left(8 \mathrm{H}, \mathrm{m},-\mathrm{CH}_{2}-\right)$, $3.30\left(8 \mathrm{H}, \mathrm{t}, \mathrm{Cl}-\mathrm{CH}_{2}-\mathrm{CH}_{2}-\right), 3.76\left(8 \mathrm{H}, \mathrm{t}, \mathrm{CH}_{2}-\mathrm{O}-\right), 7.24(8 \mathrm{H}, \mathrm{s}$, Ar- $H) .{ }^{13} \mathrm{C}-\mathrm{NMR}\left(\mathrm{CDCl}_{3}, 125 \mathrm{MHz}\right) \delta(\mathrm{ppm})=30.4,31.3,32.2$, $34.4,67.0,125.2,128.1,146.4,156.3$.

25,26,27,28-tetrakis [(3-bromopropyl)thio]-5,11,17,23-tetratert-butyl-2,8,14,20-tetrathiacalix [4] arene $\left(7^{\prime}\right)^{34}$
Under argon, a mixture of TMTCA $2(0.4 \mathrm{~g}, 0.51 \mathrm{mmol})$ and $\mathrm{Cs}_{2} \mathrm{CO}_{3}(3.32 \mathrm{~g}, 10.2 \mathrm{mmol})$ in dry and degassed acetone (60 $\mathrm{mL}$ ) was refluxed for 2 hours. Then, 1,3-dibromopropane (1 $\mathrm{mL}, 10.2 \mathrm{mmol}$ ) was added. The reaction mixture was refluxed for 60 hours under argon. After cooling, the reaction mixture was filtrated and the organic solution was evaporated to dryness. The crude residue was recrystallized from a $\mathrm{CH}_{2} \mathrm{Cl}_{2}-\mathrm{MeOH}$ $1 / 10$ mixture $(50 \mathrm{~mL})$ affording to desired pure product $7^{\prime}$ in $1,3-A$ conformation as a white solid $(0.52 \mathrm{~g}, 80 \%$ yield $) . \mathrm{mp}=$ $310{ }^{\circ} \mathrm{C}$ (decomp.) ${ }^{1} \mathrm{H}-\mathrm{NMR}\left(\mathrm{CDCl}_{3}, 300 \mathrm{MHz}\right): 1.32(36 \mathrm{H}, \mathrm{s}$, $\left.\mathrm{C}\left(\mathrm{CH}_{3}\right)_{3}\right), 1.89\left(8 \mathrm{H}, \mathrm{m},-\mathrm{CH}_{2}-\right), 3.06\left(8 \mathrm{H}, \mathrm{t},-\mathrm{CH}_{2}-\mathrm{Br}\right), 3.71(8 \mathrm{H}$, t, $\left.-\mathrm{S}-\mathrm{CH}_{2}-\right), 7.69(8 \mathrm{H}, \mathrm{s}, \mathrm{Ar}-H) .{ }^{13} \mathrm{C}-\mathrm{NMR}\left(125 \mathrm{MHz}, \mathrm{CDCl}_{3}\right)$ : $30.5,31.4,32.3,34.5,67.1,127.3,128.2,146.5,156.3$.

\section{5,26,27,28-tetrakis[(1-ethyl-1H-pyrazole)]-5,11,17,23-tetra-} tert-butyl-2,8,14,20-thiacalix [4] arene (3)

A mixture of pyrazole $(0.36 \mathrm{~g}, 5.23 \mathrm{mmol})$ and $\mathrm{NaH}(0.21 \mathrm{~g}$, $5.23 \mathrm{mmol}$ ) was stirred at room temperature in dry DMF (50 $\mathrm{mL})$ for 1 hour. Then 3 ' $(0.5 \mathrm{~g}, 0.43 \mathrm{mmol})$ was added and the solution was heated to $100{ }^{\circ} \mathrm{C}$ and stirred for $12 \mathrm{~h}$. The solvent was evaporated to dryness and the residue was dissolved in $\mathrm{CHCl}_{3}(50 \mathrm{~mL})$ and washed with $\mathrm{NaHCO}_{3}(10 \%, 50 \mathrm{~mL})$ and with $\mathrm{H}_{2} \mathrm{O}(3 \times 50 \mathrm{~mL}) . \mathrm{CHCl}_{3}$ was evaporated and compound 3 in $1,3-A$ conformation was obtained as a white solid $(0.39 \mathrm{~g}, 69 \%$ yield) by precipitation in ether $(100 \mathrm{ml}) \cdot \mathrm{mp}=262{ }^{\circ} \mathrm{C} .{ }^{1} \mathrm{H}-$ $\mathrm{NMR}\left(\mathrm{CDCl}_{3}, 500 \mathrm{MHz}\right) \delta(\mathrm{ppm})=1.13\left(36 \mathrm{H}, \mathrm{s}, \mathrm{C}\left(\mathrm{CH}_{3}\right)_{3}\right)$, $3.89\left(8 \mathrm{H}, \mathrm{t},-\mathrm{CH}_{2}-\mathrm{Pyr}\right), 4.34$ (8H, t, O-CH2-), 6.13 (4H, t, Pyr- $H$ ), $7.11(4 \mathrm{H}, \mathrm{d}$, Pyr-H), $7.40(8 \mathrm{H}, \mathrm{s}, \mathrm{Ar}-H), 7.42(4 \mathrm{H}, \mathrm{d}$, PyrH). ${ }^{13} \mathrm{C}-\mathrm{NMR}\left(\mathrm{CDCl}_{3}, 125 \mathrm{MHz}\right) \delta(\mathrm{ppm})=31.1,34.3,50.3$, $67.4,105.5,128,128.2,128.8,139.1,147.3$, 156.6. MS (ESI) $\mathrm{m} / \mathrm{z}=1097.45(\mathrm{M})^{+}$, (calculated 1097.46). Anal. Calcd. for $\mathrm{C}_{60} \mathrm{H}_{72} \mathrm{~N}_{8} \mathrm{O}_{4} \mathrm{~S}_{4}: \mathrm{C}, 65.66 \%, \mathrm{H}, 6.61 \%, \mathrm{~N}, 10.21 \%$; Found: C, $65.73 \%, \mathrm{H}, 6.70 \%$, N, $10.25 \%$.

\section{5,26,27,28-tetrakis [(1-propyl-1H-pyrazole)]-5,11,17,23- tetra-tert-butyl-2,8,14,20-thiacalix [4] arene (4)}

A mixture of pyrazole $(0.27 \mathrm{~g}, 3.98 \mathrm{mmol})$ and $\mathrm{NaH}(0.16 \mathrm{~g}$, $3.98 \mathrm{mmol}$ ) was stirred at room temperature in dry DMF (50 $\mathrm{mL})$ for 1 hour. Then 4' $(0.4 \mathrm{~g}, 0.33 \mathrm{mmol})$ was added and the solution was stirred and heated to $100{ }^{\circ} \mathrm{C}$ for $12 \mathrm{~h}$. The solvent was evaporated to dryness, the residue dissolved in $\mathrm{CHCl}_{3}$ (50 $\mathrm{mL})$ and washed with $\mathrm{NaHCO}_{3}(10 \%, 50 \mathrm{~mL})$ and with $\mathrm{H}_{2} \mathrm{O}(3$ x $50 \mathrm{~mL}$ ) and filtrated. $\mathrm{CHCl}_{3}$ was removed and the mixture was purified by column chromatography on $\mathrm{SiO}_{2}$ (EtOAc/cyclohexane $\left.=1 / 4, \mathrm{R}_{\mathrm{f}}=0.9\right)$ affording to a desired product 4 in $1,3-A$ conformation as a white powder $(0.21 \mathrm{~g}, 55 \%$ yield). $\mathrm{mp}=327{ }^{\circ} \mathrm{C} .{ }^{1} \mathrm{H}-\mathrm{NMR}\left(\mathrm{CDCl}_{3}, 300 \mathrm{MHz}\right) \delta(\mathrm{ppm})=$ $1.14\left(36 \mathrm{H}, \mathrm{s}, \mathrm{C}\left(\mathrm{CH}_{3}\right)_{3}\right), 1.59\left(8 \mathrm{H}, \mathrm{m},-\mathrm{CH}_{2}-\right), 3.91\left(8 \mathrm{H}, \mathrm{t},-\mathrm{CH}_{2}-\right.$ Pyr), 3.91 (8H, t, O-CH2-), $6.17(4 \mathrm{H}, \mathrm{t}, \mathrm{Pyr}-H), 7.26(4 \mathrm{H}, \mathrm{d}$, Pyr-H), 7.28 (8H, s, Ar- $H), 7.44(4 \mathrm{H}, \mathrm{d}$, Pyr- $H) .{ }^{13} \mathrm{C}-\mathrm{NMR}$ $\left(\mathrm{CDCl}_{3}, 125 \mathrm{MHz}\right) \delta(\mathrm{ppm})=30.0,31.2,34.2,49.3,66.4,105.3$, $127.7,128.1,128.8,139.0,146.2,156.6$. MS (ESI) $\mathrm{m} / \mathrm{z}=$ $1170.56\left[\mathrm{M}+\mathrm{H}_{2} \mathrm{O}\right]^{+}$(calculated 1170.52). Anal. Calcd. for $\mathrm{C}_{64} \mathrm{H}_{80} \mathrm{~N}_{8} \mathrm{O}_{4} \mathrm{~S}_{4}: \mathrm{C}, 66.63 \%, \mathrm{H}, 6.99 \%$, N, $9.71 \%$; Found: $\mathrm{C}$, $66.53 \%, \mathrm{H}, 7.13 \%, \mathrm{~N}, 9.50 \%$. 
25,26,27,28-tetrakis [(1-butyl-1 $H$-pyrazole)]-5,11,17,23-tetratert-butyl-2,8,14,20-tetrathiacalix[4]arene (5)

A mixture of pyrazole $(0.47 \mathrm{~g}, 6.9 \mathrm{mmol})$ and $\mathrm{NaH}(0.16 \mathrm{~g}, 6.9$ $\mathrm{mmol})$ was stirred at room temperature in dry DMF $(50 \mathrm{~mL})$ for 1 hour. Then compound 5' $(0.5 \mathrm{~g}, 0.46 \mathrm{mmol})$ was added and the solution was stirred and heated to $100{ }^{\circ} \mathrm{C}$ for $12 \mathrm{~h}$. The solvent was evaporated to dryness and the residue dissolved in $\mathrm{CHCl}_{3}(50 \mathrm{~mL})$ and washed with $\mathrm{NaHCO}_{3}(10 \%, 50 \mathrm{~mL})$ and with $\mathrm{H}_{2} \mathrm{O}(3 \times 50 \mathrm{~mL})$. $\mathrm{CHCl}_{3}$ was removed and the compound 5 in $1,3-A$ conformation was obtained as a white powder $(0.28$ g, $51 \%$ yield) after purification by column chromatography on $\mathrm{SiO}_{2}\left(\mathrm{CH}_{2} \mathrm{Cl}_{2} / \mathrm{CH}_{3} \mathrm{OH}=97 / 3, \mathrm{R}_{\mathrm{f}}=0.7\right) . \mathrm{mp}=228{ }^{\circ} \mathrm{C} .{ }^{1} \mathrm{H}-\mathrm{NMR}$ $\left(\mathrm{CDCl}_{3}, 300 \mathrm{MHz}\right) \delta(\mathrm{ppm})=1.21\left(36 \mathrm{H}, \mathrm{s}, \mathrm{C}\left(\mathrm{CH}_{3}\right)_{3}\right), 1.31(8 \mathrm{H}$, $\left.\mathrm{m},-\mathrm{CH}_{2}-\right), 1.80\left(8 \mathrm{H}, \mathrm{m},-\mathrm{CH}_{2}-\right), 3.89\left(8 \mathrm{H}, \mathrm{t},-\mathrm{CH}_{2}-\mathrm{Pyr}\right), 4.03$ $\left(8 \mathrm{H}, \mathrm{t}, \mathrm{O}-\mathrm{CH}_{2}-\right), 6.22$ (4H, t, Pyr-H), $7.31(4 \mathrm{H}, \mathrm{d}, \mathrm{Pyr}-H), 7.33$ $(4 \mathrm{H}, \mathrm{d}$, Pyr- $H), 7.48$ (4H, d, Pyr- $H) .{ }^{13} \mathrm{C}-\mathrm{NMR}\left(\mathrm{CDCl}_{3}, 125\right.$ $\mathrm{MHz}) \delta(\mathrm{ppm})=26.3,26.9,31.4,34.2,51.6,69,105.3,128.4$, $128.8,129.3,139.3,145.5,157.5$. MS (MALDI-TOF) $\mathrm{m} / \mathrm{z}=$ $1231.60 \quad[\mathrm{M}+\mathrm{Na}]^{+}$(calculated 1231.57). Anal. Calcd. for $\mathrm{C}_{68} \mathrm{H}_{88} \mathrm{~N}_{8} \mathrm{O}_{4} \mathrm{~S}_{4} \cdot \mathrm{H}_{2} \mathrm{O}$ : C, 66.52\%, H, 7.39\%, N, 9.13\%; Found: C, $66.64 \%, \mathrm{H}, 7.37 \%, \mathrm{~N}, 9.02 \%$.

\section{5,26,27,28-tetrakis [(1-ethyl-1H-pyrazole)thio]-5,11,17,23- tetra-tert-butyl-2,8,14,20-tetrathiacalix[4] arene (6)}

A mixture of TMTCA $2(0.2 \mathrm{~g}, 0.25 \mathrm{mmol})$ and $\mathrm{Cs}_{2} \mathrm{CO}_{3}(1.66 \mathrm{~g}$, $5.1 \mathrm{mmol})$ in dry and degassed acetone $(50 \mathrm{ml})$ was refluxed for 2 hours. Then 1-(2-bromoethyl)-1H-pyrazole ( $0.45 \mathrm{~g}, 2.5 \mathrm{mmol})$ was added and the mixture was refluxed for 60 hours under argon. After cooling, the solid residue was filtrated and washed with $\mathrm{CH}_{2} \mathrm{Cl}_{2}(100 \mathrm{ml}) . \mathrm{CH}_{2} \mathrm{Cl}_{2}$ was evaporated and the mixture was purified by column chromatography on $\mathrm{Al}_{2} \mathrm{O}_{3}\left(\mathrm{CH}_{2} \mathrm{Cl}_{2}, \mathrm{R}_{\mathrm{f}}\right.$ $=0.5)$ the pure compound 6 as a white solid $(0.15 \mathrm{~g}$, yield $50 \%) . \mathrm{mp}=255{ }^{\circ} \mathrm{C}$ (decomp.). ${ }^{1} \mathrm{H}-\mathrm{NMR} \delta\left(\mathrm{CDCl}_{3}, 300 \mathrm{MHz}\right)$ $=1.17\left(36 \mathrm{H}, \mathrm{s}, \mathrm{C}\left(\mathrm{CH}_{3}\right)_{3}\right), 3.47\left(8 \mathrm{H}, \mathrm{t},-\mathrm{CH}_{2}-\right), 4.18(8 \mathrm{H}, \mathrm{t}, \mathrm{S}-$ $\left.\mathrm{CH}_{2}-\right), 6.26$ (4H, t, Pyr-H), 7.54 (4H, d, Pyr- $\left.H\right), 7.64$ (8H, s, Ar$H), 7.70(4 \mathrm{H}, \mathrm{d}, \mathrm{Pyr}-H) .{ }^{13} \mathrm{C}-\mathrm{NMR} \delta\left(\mathrm{CDCl}_{3}, 125 \mathrm{MHz}\right)=30.9$, $34.5,35.9 ; 52.0,105.1,130.7,135.9,139.6,139.8,142.3,150.3$ MS (MALDI-TOF) $\mathrm{m} / \mathrm{z}=1161.77(\mathrm{M})^{+}$(calculated 1161.37), $1184.39(\mathrm{M}+\mathrm{Na})^{+}$(calculated 1184.36). Anal. Calcd. for $\mathrm{C}_{60} \mathrm{H}_{72} \mathrm{~N}_{8} \mathrm{~S}_{8}: \mathrm{C}, 62.03 \%, \mathrm{H}, 6.25 \%, \mathrm{~N}, 9.64 \%$; Found: C, $62.61 \%, H, 6.32 \%$, N, $9.69 \%$.

25,26,27,28-tetrakis [(1-propyl-1H-pyrazole)thio]-5,11,17,23tetra-tert-butyl-2,8,14,20-tetrathiacalix[4] arene (7)

A mixture of pyrazole $(0.26 \mathrm{~g}, 3.8 \mathrm{mmol})$ and $\mathrm{NaH}(0.1 \mathrm{~g}, 4.26$ $\mathrm{mmol})$ was stirred at room temperature in dry DMF $(50 \mathrm{~mL})$ for 1 hour. Then compound 7' $(0.25 \mathrm{~g}, 0.2 \mathrm{mmol})$ was added. The reaction mixture was stirred at the room temperature and under argon during 48 hours. The solvent was evaporated to dryness and the solid residue was washed with $\mathrm{CH}_{2} \mathrm{Cl}_{2}(50 \mathrm{~mL})$ and filtrated. The solvent was removed and the desired compound 7 was obtained as a white powder after treating the crude residue with $\mathrm{MeOH}(50 \mathrm{ml})(0.15 \mathrm{~g}, 62 \%$ yield $) . \mathrm{mp}=210{ }^{\circ} \mathrm{C}$ (decomp.). ${ }^{1} \mathrm{H}-\mathrm{NMR} \delta\left(\mathrm{CDCl}_{3}, 300 \mathrm{MHz}\right): 1.24(36 \mathrm{H}, \mathrm{s}$, $\left.\mathrm{C}\left(\mathrm{CH}_{3}\right)_{3}\right), 1.94\left(8 \mathrm{H}, \mathrm{m},-\mathrm{CH}_{2}-\right), 2.85\left(8 \mathrm{H}, \mathrm{t},-\mathrm{CH}_{2}-\right), 4.37(8 \mathrm{H}, \mathrm{t}$, S-CH2-), 6.19 (4H, t, Pyr-H), $7.35(4 \mathrm{H}, \mathrm{d}, \operatorname{Pyr}-H), 7.50(4 \mathrm{H}, \mathrm{d}$,
Pyr-H), 7.69 (8H, s, Ar- $H) .{ }^{13} \mathrm{C}-\mathrm{NMR} \delta\left(\mathrm{CDCl}_{3}, 125 \mathrm{MHz}\right)$ : 30.2, 31.2, 32.3, 34.7, 50.9, 105.3, 129.7, 133.9, 139.5, 139.7, 142.5, 150.5. MS (MALDI-TOF) $\mathrm{m} / \mathrm{z}=1239.4[\mathrm{M}+\mathrm{Na}]^{+}$ (calculated 1240.42). Anal. Calcd. for $\mathrm{C}_{64} \mathrm{H}_{80} \mathrm{~N}_{8} \mathrm{~S}_{8}: 63.12 \%, \mathrm{H}$, $6.62 \%$, N, 9.20\%; Found: $63.45 \%$, H, 6.85\%, N, 9.30\%.

\section{5,26,27,28-tetrakis[(1-butyl-1H-pyrazole)thio]-5,11,17,23- tetra-tert-butyl-2,8,14,20-tetrathiacalix [4] arene (8)}

A mixture of TMTCA $2(0.2 \mathrm{~g}, 0.25 \mathrm{mmol})$ and $\mathrm{Cs}_{2} \mathrm{CO}_{3}(1.66 \mathrm{~g}$, $5.1 \mathrm{mmol})$ in dry and degassed acetone $(50 \mathrm{~mL})$ was refluxed for 2 hours. Then 1-(4-bromobutyl)-1H-pyrazole (0.52 g, 2.5 mmol) was added and the mixture was refluxed for 60 hours under argon. After cooling, the reaction mixture was filtrated and evaporated. The residue was purified by column chromatography on $\mathrm{SiO}_{2}\left(\right.$ cyclohexane/EtOAc $=1 / 1, \mathrm{R}_{\mathrm{f}}=0.9$ ) and $\mathrm{Al}_{2} \mathrm{O}_{3}\left(\mathrm{CH}_{2} \mathrm{Cl}_{2}, \mathrm{R}_{\mathrm{f}}=0.5\right)$ affording to a desired product 8 as a white powder $(0.14 \mathrm{~g}, 44 \%$ yield $) . \mathrm{mp}=265{ }^{\circ} \mathrm{C}$ (decomp.). ${ }^{1} \mathrm{H}-\mathrm{NMR} \delta\left(\mathrm{CDCl}_{3}, 300 \mathrm{MHz}\right)=1.21\left(36 \mathrm{H}, \mathrm{s}, \mathrm{C}\left(\mathrm{CH}_{3}\right)_{3}\right), 1.43$ $\left(8 \mathrm{H}, \mathrm{m},-\mathrm{CH}_{2}-\right), 2.09\left(8 \mathrm{H}, \mathrm{m}, \mathrm{X}-\mathrm{CH}_{2}-\mathrm{X}\right), 2.91\left(8 \mathrm{H}, \mathrm{t}, \mathrm{X}-\mathrm{CH}_{2}-\right.$ $\mathrm{X}), 4.19$ (8H, t, S-CH $\left.2_{2}^{-}\right), 6.25$ (4H, t, Pyr-H), 7.39 (4H, d, Pyr$H), 7.52(4 \mathrm{H}, \mathrm{d}$, Pyr- $H), 7.66(4 \mathrm{H}, \mathrm{d}$, Pyr- $H) .{ }^{13} \mathrm{C}-\mathrm{NMR} \delta$ $\left(\mathrm{CDCl}_{3}, 125 \mathrm{MHz}\right)=25.6,28.9,30.0,33.5,34.3,50.8,104.4$, $128.0,133.7,138.2,139.6,141.6,148.6$. MS (MALDI-TOF) $\mathrm{m} / \mathrm{z}=1273.52[\mathrm{M}]^{+}$(calculated 1273.49), $1296.53[\mathrm{M}+\mathrm{Na}]^{+}$ (calculated 1296.49). Anal. Calcd. for $\mathrm{C}_{68} \mathrm{H}_{88} \mathrm{~N}_{8} \mathrm{~S}_{8}$ : C, 64.11\%, H, 6.96\%, N, 8.80\%; Found: C, 64.13\%, H, 6.94\%, N, 8.85\%

\section{Crystallization conditions}

3: a vial containing $0.5 \mathrm{~mL}$ of a $\mathrm{CHCl}_{3}$ solution of $3(5 \mathrm{mg}$, $4.55 \times 10^{-3} \mathrm{mmol}$ ) was placed in a sealed beaker containing $\mathrm{CH}_{3} \mathrm{OH}$. Slow vapour diffusion at room temperature of $\mathrm{CH}_{3} \mathrm{OH}$ produced colourless crystals suitable for X-ray diffraction after several days.

6: $1 \mathrm{~mL}$ of a $\mathrm{CH}_{2} \mathrm{Cl}_{2}$ solution of $6\left(5 \mathrm{mg}, 4.31 \times 10^{-3} \mathrm{mmol}\right)$ was mixed with $1 \mathrm{ml}$ of $\mathrm{CH}_{3} \mathrm{OH}$. Slow evaporation at room temperature produced colourless crystals suitable for X-ray diffraction after several days.

5-AgSbF 6 : In a crystallization tube $(20 \times 4 \mathrm{~mm})$, a solution of compound 5 (5 mg, $\left.4.13 \times 10^{-3} \mathrm{mmol}\right)$ in $\mathrm{CHCl}_{3}(1 \mathrm{~mL})$ was layered with a $\mathrm{CHCl}_{3} / \mathrm{CH}_{3} \mathrm{OH}(1 / 1)$ mixture $(0.1 \mathrm{~mL})$. A solution of $\mathrm{AgSbF}_{6}\left(4.3 \mathrm{mg}, 12.39 \times 10^{-3} \mathrm{mmol}\right)$ in $\mathrm{CH}_{3} \mathrm{OH}$ (1 $\mathrm{mL}$ ) was carefully added. At room temperature, slow diffusion in the dark produced colourless crystals suitable for X-ray diffraction after several days $(4.1 \mathrm{mg}, 71 \%$ yield). Anal. Calcd. for $\left[\mathrm{C}_{68} \mathrm{H}_{88} \mathrm{~N}_{8} \mathrm{O}_{4} \mathrm{~S}_{4}, \mathrm{AgSbF}_{6} \cdot\left(\mathrm{CHCl}_{3}\right)_{5}\right]: \mathrm{C}, 40.78 \%, \mathrm{H}, 4.36 \%, \mathrm{~N}$, $5.21 \%$. Found: C, $40.05 \%, \mathrm{H}, 3.98 \%$, N, $5.75 \%$.

5-AgBF 4 : In a crystallization tube $(20 \times 4 \mathrm{~mm})$, a solution of compound 5 ( $\left.5 \mathrm{mg}, 4.13 \times 10^{-3} \mathrm{mmol}\right)$ in $\mathrm{CH}_{2} \mathrm{Cl}_{2}(1 \mathrm{~mL})$ was layered with $\mathrm{CH}_{2} \mathrm{Cl}_{2} / \mathrm{CH}_{3} \mathrm{OH}(1 / 1)$ mixture $(0.1 \mathrm{~mL})$. A solution of $\mathrm{AgBF}_{4}\left(2.4 \mathrm{mg}, 12.39 \times 10^{-3} \mathrm{mmol}\right)$ in $\mathrm{CH}_{3} \mathrm{OH}$ (1 $\mathrm{mL}$ ) was carefully added. At room temperature, slow diffusion 
in the dark produced colourless crystals suitable for X-ray diffraction after several days (3.9 mg, $67 \%$ yield). Anal. Calcd. for $\left[\mathrm{C}_{68} \mathrm{H}_{88} \mathrm{~N}_{8} \mathrm{O}_{4} \mathrm{~S}_{4}, \mathrm{AgBF}_{4} \cdot\left(\mathrm{H}_{2} \mathrm{O}\right)_{3}\right]: \mathrm{C}, 56.00 \%, \mathrm{H}, 6.50 \%, \mathrm{~N}$, $7.68 \%$; Found: C, 56.54\%, H, 6.72\%, N, 7.62\%.

\section{6-AgBF 4 :}

In a crystallization tube (diameter $4 \mathrm{~mm}$, height $15 \mathrm{~cm}$ ), a solution of 6 ( $\left.3 \mathrm{mg}, 2.6 \times 10^{-3} \mathrm{mmol}\right)$ in $\mathrm{CHCl}_{3}(1 \mathrm{~mL})$ was layered with a $\mathrm{CHCl}_{3} /$ iso- $\mathrm{PrOH}(1 / 1)$ mixture $(0.1 \mathrm{~mL})$. A solution of $\mathrm{AgBF}_{4}\left(1 \mathrm{mg}, 5.2 \times 10^{-3} \mathrm{mmol}\right)$ in $\mathrm{MeOH}(1 \mathrm{~mL})$ was carefully added. Slow diffusion at room temperature and in the dark produced after 2 weeks colourless crystals (2.2 mg, $58 \%$ yield) suitable for $\mathrm{X}$-ray diffraction. Anal. Calcd. for $\left[\left(\mathrm{C}_{30} \mathrm{H}_{36} \mathrm{~N}_{4} \mathrm{~S}_{4} \mathrm{AgBF}_{4}\right)_{2} \cdot \mathrm{H}_{2} \mathrm{O}\right]: \mathrm{C}, 45,93 \%, \mathrm{H}, 4,75 \%, \mathrm{~N}, 7,14 \%$; Found: C, 46,15\%; H, 4,8\%; N, 7,25\%.

\section{6-AgPF}

In a crystallization tube (diameter $4 \mathrm{~mm}$, height $15 \mathrm{~cm}$ ), a solution of 6 (3 mg, $\left.2.6 \times 10^{-3} \mathrm{mmol}\right)$ in $\mathrm{CH}_{2} \mathrm{Cl}_{2}(1 \mathrm{~mL})$ was layered with a $\mathrm{CH}_{2} \mathrm{Cl}_{2} / \mathrm{EtOH}(1 / 1)$ mixture $(0.1 \mathrm{~mL})$. A solution of $\mathrm{AgPF}_{6}\left(1.3 \mathrm{mg}, 5.2 \times 10^{-3} \mathrm{mmol}\right)$ in $\mathrm{EtOH}(1 \mathrm{~mL})$ was carefully added. Slow diffusion at room temperature and in the dark produced after 2 weeks colourless crystals (2.2 mg, $51 \%$ yield) suitable for X-ray diffraction. Anal. Calcd. for $\left[\mathrm{C}_{30} \mathrm{H}_{36} \mathrm{~N}_{4} \mathrm{~S}_{4} \mathrm{AgPF}_{6} \cdot\left(\mathrm{H}_{2} \mathrm{O}\right)_{3}\right]: \mathrm{C}, 40.59 \%, \mathrm{H}, 4.77 \%$, N, $6.31 \%$; Found: C, $40.81 \%$; H, $4.82 \%$; N, $6.34 \%$.

\section{6-AgSbF :}

In a crystallization tube (diameter $4 \mathrm{~mm}$, height $15 \mathrm{~cm}$ ), a solution of 6 (3 mg, $\left.2.6 \times 10^{-3} \mathrm{mmol}\right)$ in $\mathrm{CH}_{2} \mathrm{Cl}_{2}(1 \mathrm{~mL})$ was layered with a $\mathrm{CH}_{2} \mathrm{Cl}_{2} / \mathrm{EtOH}(1 / 1)$ mixture $(0.1 \mathrm{~mL})$. A solution of $\mathrm{AgSbF}_{6}\left(1.8 \mathrm{mg}, 5.2 \times 10^{-3} \mathrm{mmol}\right)$ in $\mathrm{EtOH}(1 \mathrm{~mL})$ was carefully added. Slow diffusion at room temperature and in the dark produced after 2 weeks colourless crystals $(2.8 \mathrm{mg}, 59 \%$ yield) suitable for $\mathrm{X}$-ray diffraction. Anal. Calcd. for $\left[\mathrm{C}_{30} \mathrm{H}_{36} \mathrm{~N}_{4} \mathrm{~S}_{4} \mathrm{AgSbF}_{6} \cdot\left(\mathrm{H}_{2} \mathrm{O}\right)_{3}\right]: \mathrm{C}, 36.82 \%, \mathrm{H}, 4.33 \%$, N, $5.73 \%$ Found: C, $36.98 \%, \mathrm{H}, 4.45 \%$, N, $5.76 \%$.

\section{6-AgAsF 6 :}

In a crystallization tube (diameter $4 \mathrm{~mm}$, height $15 \mathrm{~cm}$ ), a solution of $6\left(3 \mathrm{mg}, 2.6 \times 10^{-3} \mathrm{mmol}\right)$ in $\mathrm{CH}_{2} \mathrm{Cl}_{2}(1 \mathrm{~mL})$ was layered with a $\mathrm{CH}_{2} \mathrm{Cl}_{2} / \mathrm{EtOH}(1 / 1)$ mixture $(0.1 \mathrm{~mL})$. A solution of $\mathrm{AgAsF}_{6}\left(1.5 \mathrm{mg}, 5.2 \times 10^{-3} \mathrm{mmol}\right)$ in EtOH $(1 \mathrm{~mL})$ was carefully added. Slow diffusion at room temperature and in the dark produced after 2 weeks colourless crystals $(2.7 \mathrm{mg}, 60 \%$ yield) suitable for X-ray diffraction. Anal. Calcd. for $\left[\mathrm{C}_{30} \mathrm{H}_{36} \mathrm{~N}_{4} \mathrm{~S}_{4} \operatorname{AgAsF}_{6} \cdot\left(\mathrm{H}_{2} \mathrm{O}\right)_{3}\right]: \mathrm{C}, 38.67 \%, \mathrm{H}, 4.54 \%, \mathrm{~N}$, $6.01 \%$; Found: C, $38.81 \%, \mathrm{H}, 4.58 \%, \mathrm{~N}, 6.06 \%$.

\section{7-AgSbF 6 :}

In a crystallization tube (diameter $4 \mathrm{~mm}$, height $15 \mathrm{~cm}$ ), a solution of 7 ( $\left.5 \mathrm{mg}, 4.1 \times 10^{-3} \mathrm{mmol}\right)$ in $\mathrm{CHCl}_{3}(1 \mathrm{~mL})$ was layered with a $\mathrm{CHCl}_{3} /$ iso- $\mathrm{PrOH}(1 / 1)$ mixture $(0.1 \mathrm{~mL})$. A solution of $\mathrm{AgSbF}_{6}\left(2.8 \mathrm{mg}, 8.2 \times 10^{-3} \mathrm{mmol}\right)$ in $\mathrm{MeOH}(1 \mathrm{~mL})$ was carefully added. Slow diffusion at room temperature and in the dark produced after 2 weeks colourless crystals $(2.5 \mathrm{mg}$,
$53 \%$ yield) suitable for X-ray diffraction. Anal. Calcd. for $\left[\mathrm{Ag}_{2}\left(\mathrm{C}_{64} \mathrm{H}_{80} \mathrm{~N}_{8} \mathrm{~S}_{8}\right)\left(\mathrm{SbF}_{6}\right)_{2} \cdot\left(\mathrm{CHCl}_{3}\right)_{2}\right]: \mathrm{C}, 36.98 \%, \mathrm{H}, 3.86 \%, \mathrm{~N}$, $5.23 \%$; Found: C, $37.10 \%$, H, $3.90 \%$, N, $5.21 \%$.

\section{8-AgSbF 6 :}

In a crystallization tube $(20 \times 4 \mathrm{~mm})$, a solution of $\mathbf{8}(3 \mathrm{mg}, 2.3$ x $\left.10^{-3} \mathrm{mmol}\right)$ in $\mathrm{CHCl}_{3}(1 \mathrm{~mL})$ was layered with $\mathrm{CHCl}_{3} /$ isoPrOH $(1 / 1)$ mixture $(0.1 \mathrm{~mL})$. A solution of $\mathrm{AgSbF}_{6}(1.6 \mathrm{mg}$, $\left.4.6 \times 10^{-3} \mathrm{mmol}\right)$ in $\mathrm{MeOH}(1 \mathrm{~mL})$ was carefully added. At room temperature, slow diffusion in the dark produced colourless crystals suitable for X-ray diffraction after 1 month (2.0 mg, $43 \%$ yield). Anal. Calcd. for $\left[\mathrm{Ag}_{4}\left(\mathrm{C}_{68} \mathrm{H}_{88} \mathrm{~N}_{8} \mathrm{~S}_{8}\right)\right.$ $\left.2\left(\mathrm{SbF}_{6}\right)_{4} \cdot\left(\mathrm{CHCl}_{3}\right)_{7} \cdot\left(\mathrm{H}_{2} \mathrm{O}\right)_{2}\right]: \mathrm{C}, 35.83 \%, \mathrm{H}, 3.93 \%, \mathrm{~N}, 4.67 \%$ Found: C, $36.11 \%, \mathrm{H}, 4.01 \%, \mathrm{~N}, 4.75 \%$.

\section{8- $\mathrm{AgNO}_{3}:$}

In a crystallization tube $(20 \times 4 \mathrm{~mm})$, a solution of $\mathbf{8}(3 \mathrm{mg}, 2.3$ x $\left.10^{-3} \mathrm{mmol}\right)$ in $\mathrm{CHCl}_{3}(1 \mathrm{~mL})$ was layered with $\mathrm{CHCl}_{3}$ /iso$\mathrm{PrOH}(1 / 1)$ mixture $(0.1 \mathrm{~mL})$. A solution of $\mathrm{AgNO}_{3}(0.8 \mathrm{mg}$, $\left.4.6 \times 10^{-3} \mathrm{mmol}\right)$ in $\mathrm{MeOH}(1 \mathrm{~mL})$ was carefully added. At room temperature, slow diffusion in the dark produced colourless crystals suitable for X-ray diffraction after 1 month (1.9 mg $50 \%$ yield). Anal. Calcd. for $\left[\mathrm{C}_{34} \mathrm{H}_{44} \mathrm{~N}_{4} \mathrm{~S}_{4} \mathrm{AgNO}_{3} \cdot \mathrm{H}_{2} \mathrm{O}\right]$ : C, 49.51\%, H, 5.62\%, N, 8.49\%; Found: C, 50.12\%, H, 5.70\%, $\mathrm{N}, 8.54 \%$.

\section{Structural studies Single-Crystal Studies}

Data were collected at 173(2) K on a Bruker SMART CCD diffractometer equipped with an Oxford Cryosystem liquid $\mathrm{N}_{2}$ device, using graphite-monochromated Mo-K $\alpha(\lambda=0.71073 \AA)$ radiation. For all structures, diffraction data were corrected for absorption. Structures were solved using SHELXS-97 and refined by full matrix least-squares on $F^{2}$ using SHELXL-97. The hydrogen atoms were introduced at calculated positions and refined using a riding model. ${ }^{35}$ They can be obtained free of charge from the Cambridge Crystallographic Data Centre via www.ccdc.cam.ac.uk/datarequest/cif. $\quad$ CCDC: 14383581438368

\section{Powder diffraction studies (PXRD)}

Diagrams were collected on a Bruker D8 diffractometer using monochromatic $\mathrm{Cu}-\mathrm{K} \alpha$ radiation with a scanning range between 4 and $40^{\circ}$ using a scan step size of $8 \% \mathrm{mn}$.

As already demonstrated and currently admitted, for all compounds, discrepancies in intensity between the observed and simulated patterns are due to preferential orientations of the microcrystalline powders.

\section{Results and discussion}

\section{Design and preparation of tectons}

Analogous tectons 3-5 (Figure 2) are based on the tetrathiacalix[4]arene backbone (TCA) in 1,3- $A$ conformation. The latter is functionalized with four pyrazolyl moieties 
through ether junctions using ethyl (3), propyl (4) and butyl (5) spacers. Tectons 6-8 (figure 2), based on the treramercaptotetrathiacalix[4] arene backbone (TMTCA) in 1,3$A$ conformation, are sulphur analogues of tectons 3-5 for which the $\mathrm{O}$ atoms are replaced by $\mathrm{S}$ atoms. Although calix[4]arene derivatives bearing pyrazolyl groups at the upper rim have been reported, ${ }^{36}$ to the best of our knowledge, no TCA or TMTCA pyrazolyl appended tectons have been described so far in the literature. However, pyrazolyl appended $[1,1,1,1]$ metacyclophane derivatives in 1,3-A conformation and their combinations with metal cation have been previously documented. ${ }^{37}$ The rational behind the use of $\left(-\mathrm{CH}_{2}\right)_{n^{-}},(\mathrm{n}=2$ 4) spacer to connect the calix backbone 1 or 2 to the coordinating pyrazolyl moiety was to investigate the role played by the flexibility of the spacer on the dimensionality and geometry of extended periodic architectures when combined with metal cations such as $\mathrm{Ag}^{+}$. The reason for the substitution of the $\mathrm{O}$ atoms in $\mathbf{1}$ (tectons $\mathbf{3}-\mathbf{5}$ ) by $\mathrm{S}$ atoms in $\mathbf{2}$, (tectons $\mathbf{6}$ 8) was to study their coordination propensity towards silver cation in the formation of the extended networks. As connecting metallic node, $\mathrm{Ag}^{+}, \mathrm{a} \mathrm{d}^{10}$ cation, was used owing to its loose coordination requirements and the reversibility of $\mathrm{Ag}^{+}$$\mathrm{N}$ bond formation. Since tectons 3-8 are neutral entities, their combinations with $\mathrm{Ag}^{+}$cation leading to the formation of cationic extended networks require the presence of anions for charge neutrality reasons. The role played by the counter ion on the formation of silver coordination networks was investigated by using different silver salts $\left(\mathrm{BF}_{4}^{-}, \mathrm{XF}_{6}{ }^{-}(\mathrm{X}=\mathrm{P}, \mathrm{As}\right.$ and $\left.\mathrm{Sb})\right)$.

The synthetic strategy used to prepare compounds 3-8 is presented in figure 2 (see experimental section for details). In order to increase the yield of the desired products in $1,3-A$ conformation, two synthetic pathways have been explored (figure 2).

Using TCA 1 as the starting material, compounds 3, 4 and 5, have been prepared in two steps. The Mitsunobu condensation between compound 1 and $\alpha$-bromoalcohol $\mathrm{Br}-\left(\mathrm{CH}_{2}\right)_{\mathrm{n}}-\mathrm{OH}(\mathrm{n}=$ 2 - 4) in dry THF in the presence of DIAD (Diisopropyl Azodicarboxylate) and $\mathrm{PPh}_{3}$ afforded the tetrabromo intermediates $3^{\prime}(n=2), 4^{\prime}(n=3)$ and $5^{\prime}(n=4)$ in $88-91 \%$ yield. The condensation of the latter with pyrazole in dry DMF in the presence of $\mathrm{NaH}$ as base afforded the desired tectons 3-5 in 69,55 and $51 \%$ yield respectively.

Tectons $6(n=2)$ and $8(n=4)$, have been obtained upon directed condensation of TMTCA 2 with bromalkylpyrazole in dry acetone in the presence of $\mathrm{Cs}_{2} \mathrm{CO}_{3}$ as base in 50 and $44 \%$ yield respectively. Compound 7 was prepared in $62 \%$ yield by condensing the TMTCA derivative $\mathbf{7}^{\mathbf{3} 4}$ with pyrazole in dry DMF in the presence of $\mathrm{NaH}$.

In all cases, only the 1,3-A conformation was isolated from the reaction mixtures.

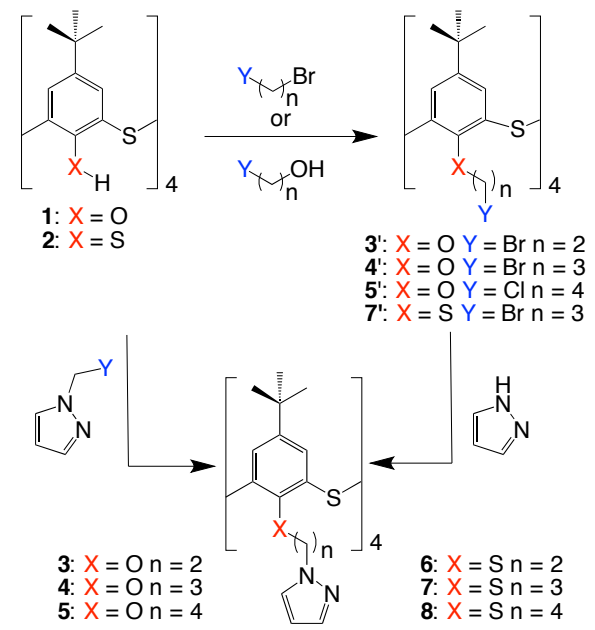

Figure 2: Two different synthetic pathways followed for the preparation of TCA and TMTCA pyrazolyl appended tectons $\mathbf{3}$ - 8 (for experimental details see experimental section).

In addition to solution characterization of all tectons 3-8, compounds 3 and $\mathbf{6}$ have been also studied by X-ray diffraction on single crystals (see crystallographic table). Crystals of $\mathbf{3}$ and 6 were obtained upon slow diffusion or slow evaporation techniques (see experimental part). As expected, both compounds are in the 1,3-A conformation in the solid state (Figure 3).

Whereas crystals of 3 contain $\mathrm{H}_{2} \mathrm{O}$ molecules, 6 crystallises in the absence of solvent molecules. For both cases, the metrics of the macrocyclic part is close to those observed for the parent compound $\mathbf{1}^{13}$ and $2^{16}$ (see table 1). For 3 , one out of the four pyrazolyl groups is found to be disordered.

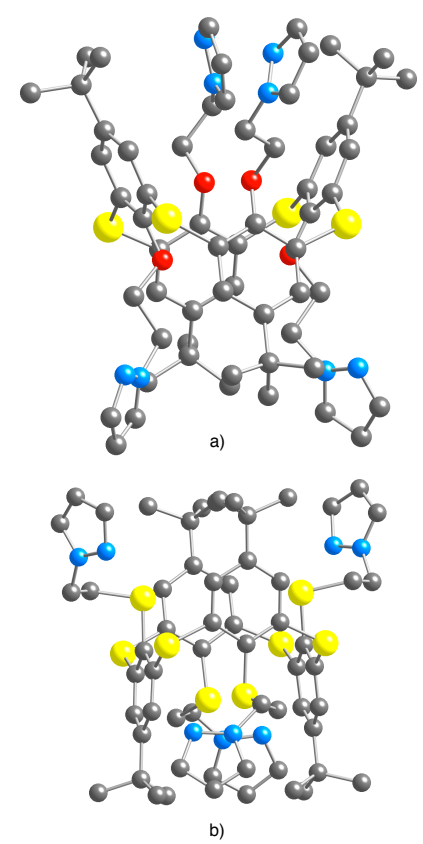

Figure 3: Solid state structures of tectons $\mathbf{3}$ and $\mathbf{6}$ in a 1,3-alternate conformation. $\mathrm{H}$ atoms and solvent molecules and disordered pyrazolyl groups are not presented for clarity. For bond distances and angles see the text. 
Table 1: Distances and angles for compounds 3 and 6 obtained by X-ray diffraction on single crystals.

\begin{tabular}{|c|c|c|}
\hline & $\mathbf{3}$ & $\mathbf{6}$ \\
\hline $\mathrm{S}-\mathrm{C}(\mathrm{Ar})$ & $1.763(6)-1.778(6)$ & $1.781(2), 1.784(2)$ and $1.785(2)$ \\
\hline $\mathrm{O}(\mathrm{S})-\mathrm{Ar}$ & $1.363(7)-1.383(7)$ & $1.777(2)$ and $1.781(2)$ \\
\hline $\mathrm{N}-\mathrm{N}($ pyrazol) & $1.336(11)-1.354(18)$ & $1.348(3)$ and $1.357(3)$ \\
\hline
\end{tabular}

For both compounds, the coordinating pyrazolyl groups are oriented almost perpendicular to the main plane formed by the four $\mathrm{S}$ atoms connecting the aromatic rings.

\section{Structural description of the networks}

For all four combinations of tectons 3-8 and $\operatorname{AgX}\left(\mathrm{X}=\mathrm{BF}_{4}\right.$, $\left.\mathrm{PF}_{6}{ }^{-}, \mathrm{SbF}_{6}{ }^{-}, \mathrm{NO}_{3}{ }^{-}\right)$salts, suitable crystals for $\mathrm{X}$-ray diffraction studies on single crystal were obtained at room temperature using slow evaporation or slow diffusion methods (see Experimental part). For air stable crystals, the purity of the crystalline phase was established by PXRD on microcrystalline powder.

The structural discussion given below is based on increasing dimensionality (1-3D) of silver coordination networks. In all cases, since bond distances and angles observed for the macrocyclic portion of tectons were found to be close to those of the parent compounds 1-3 and 6, their metrics will not be discussed.

\section{$1 D$ networks}

For the combinations of the tecton 5 with both $\mathrm{AgSbF}_{6}$ and $\mathrm{AgBF}_{4}$ silver salts, two cationic infinite 1-D non-tubular architectures were obtained (Figure 4). The same connectivity observed for both crystalline materials $\mathbf{5}-\mathrm{AgSbF}_{6}$ and $\mathbf{5}-\mathrm{AgBF}_{4}$ has been previously observed for combinations of tetrahedral silver cation with other tetra-substituted calix[4]arene ${ }^{21,29 b}$ and

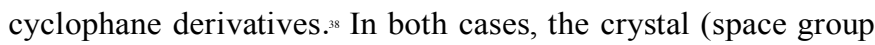
$\mathrm{P} 2(1) / c$ for $5-\mathrm{AgSbF}_{6}$ and $\mathrm{Cc}$ for $\left.5-\mathrm{AgBF}_{4}\right)$ is composed of the neutral tecton $\mathbf{5}, \mathrm{Ag}^{+}$cation, $\mathrm{BF}_{4}^{-}$or $\mathrm{SbF}_{6}^{-}$anion and solvent molecules $\left(\mathrm{CHCl}_{3}\right.$ for $\mathbf{5}-\mathrm{AgSbF}_{6}$ and $\mathrm{H}_{2} \mathrm{O}$ for $\left.\mathbf{5}-\mathrm{AgBF}_{4}\right)$. No specific interactions between the $\mathrm{Ag}^{+}$cation and anions or solvents were spotted. For both compounds, a 1/1 ligand/metal ratio is obtained. The cationic part of the network is generated by mutual bridging between the tetradentate tecton $\mathbf{5}$ and silver cation, adopting a tetrahedral coordination geometry, through pyrazolyl-silver interactions (figure 4). The other heteroatoms of $5(\mathrm{O}$ and $\mathrm{S})$ are not involved in the bonding of the metal cation. The coordination sphere around $\mathrm{Ag}^{+}$cation is composed of four $\mathrm{N}$ atoms belonging to two consecutive tectons 5 (Ag-N distances in the 2.272(3) - 2.451(3) $\AA$ range for $5-\mathrm{AgSbF}_{6}$ and 2.241(8) - 2.465(13) $\AA$ for $5-\mathrm{AgBF}_{4}$. The coordination geometry around the cation is a distorted tetrahedron (NAgN angle varying between $87.10(10)$ and $126.46(12)^{\circ}$ for $5-\mathrm{AgSbF}_{6}$ and $92.5(4)$ and $151.7(4)^{\circ}$ for $\left.\mathbf{5}-\mathrm{AgBF}_{4}\right)$. The distance between consecutive $\mathrm{Ag}^{+}$cations within the $1 \mathrm{D}$ network is $c a .16 .9 \AA$ for 5- $\mathrm{AgSbF}_{6}$ and $17.3 \AA$ for $\mathbf{5}_{-} \mathrm{AgBF}_{4}$.

The 1-D networks are packed in a parallel fashion along $b$ and $c$ axis for $\mathbf{5}-\mathrm{AgSbF}_{6}$ and along $a$ and $c$ axis for $\mathbf{5}-\mathrm{AgBF}_{4}$. No specific interactions between $\mathrm{Ag}_{+}$cation, the organic tecton $\mathbf{5}$ and solvent molecules $\left(\mathrm{H}_{2} \mathrm{O}\right.$ or $\left.\mathrm{CHCl}_{3}\right)$ are observed.
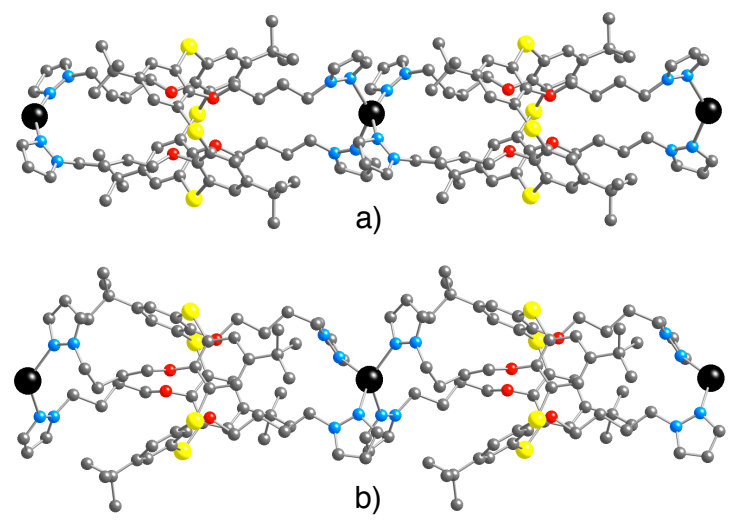

Figure 4: Portions of the solid state structures of 1D silver coordination networks $5-\mathrm{AgBF}_{4}(\mathrm{a})$ and $\mathbf{5}-\mathrm{AgSbF}_{6}$ (b) showing the mutual bridging between the coordinating tecton $\mathbf{5}$ and silver cation leading to the formation of similar cationic 1-D coordination networks. Silver cations are presented with black spheres. $\mathrm{H}$ atoms, anions and solvent molecules are not presented for sake of clarity. For bond distances and angles see text.

Owing to the decomposition of the crystals of $5-\mathrm{AgSbF}_{6}$ and 5$\mathrm{AgBF}_{4}$ in air, probably due to solvents loss, no XRPD diagrams could be recorded.

Combinations of tecton 7 with $\mathrm{AgSbF}_{6}$ or 8 with $\mathrm{AgNO}_{3}$ led to the formation of infinite cationic 1-D architectures with different type of connectivity (Figure 5) when compared to 5$\mathrm{AgSbF}_{6}$ and $\mathbf{5}_{-} \mathrm{AgBF}_{4}$ discussed above. Both networks 7$\mathrm{AgSbF}_{6}$ and 8- $\mathrm{AgNO}_{3}$ display similar type of connectivity around the metal centre. In both cases, crystals (space group $P$ 1 for $7-\mathrm{AgSbF}_{6}$ and $C 2 / c$ for $8-\mathrm{AgNO}_{3}$ ) are composed of the neutral tecton 7 or $\mathbf{8}, \mathrm{Ag}^{+}$cations with a $1 / 2$ ligand/metal ratio, $\mathrm{SbF}_{6}$ or $\mathrm{NO}_{3}$ anion and solvent molecules $\left(\mathrm{CHCl}_{3}\right.$ for $7-\mathrm{AgSbF}_{6}$ and $\mathrm{H}_{2} \mathrm{O}$ for $8-\mathrm{AgNO}_{3}$ ). In both cases, the cationic part of the network is generated by mutual interconnection of the tetradentate organic tectons and metal cations adopting a tetrahedral coordination geometry through pyrazol-silver interactions. In marked contrast with $\mathbf{5}-\mathrm{AgSbF}_{6}$ and $\mathbf{5}-\mathrm{AgBF}_{4}$ networks, here, in addition to $\mathrm{Ag}^{+} \mathrm{N}$ interactions, $\mathrm{Ag}+\mathrm{S}$ bonds are formed (Figure 5a). In the case of $\mathbf{8}-\mathrm{AgNO}_{3}$, all three types of $\mathrm{Ag}_{+-\mathrm{N}}, \mathrm{Ag}_{+-} \mathrm{S}$ and $\mathrm{Ag}_{+-\mathrm{O}}$ bonds are observed (Figure $5 \mathrm{~b}$ ). 

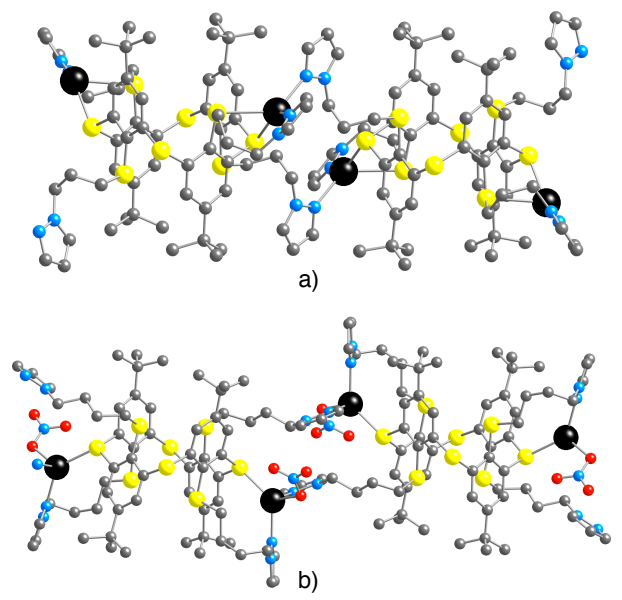

Figure 5: Portions of the solid state structures of of $1 \mathrm{D}$ silver coordination networks $7-\mathrm{AgSbF}_{6}$ (a) and $8-\mathrm{AgNO}_{3}$ (b) showing the mutual bridging between tectons $\mathbf{7}$ or $\mathbf{8}$ and silver cation leading to the formation of cationic 1-D coordination networks. Silver cations are presented with black spheres. $\mathrm{H}$ atoms, anions and solvent molecules are not presented for sake of clarity. For bond distances and angles see text.

For 7- $\mathrm{AgSbF}_{6}$, two crystallographically independent silver cations adopting a tetrahedral coordination geometry and displaying the same coordination sphere composed of two $\mathrm{N}$ atoms belonging to two consecutive tectons 7 (Ag-N distances in the $2.210(5)-2.312(4) \AA$ range) and two sulphur atoms belonging to the thioether groups as well as to the sulphur bridging atom of the thiacalixarene moiety (Ag-S in the $2.5346(13)$ - 2.9119(14) $\AA$ range) are present. The coordination geometry around the cation is again a distorted tetrahedron (NAgN angles of 101.21(18) and 103.26(18) ${ }^{\circ}, \mathrm{SAgS}$ angles of 73.07(4) and 74.11(4) ${ }^{\circ}$, and NAgS angles varying between 94.26(13) and $\left.140.88(15)^{\circ}\right)$. For 8- $\mathrm{AgNO}_{3}$, only a single type of silver cation is present. The latter is surrounded by two $\mathrm{N}$ atoms belonging to two consecutive tectons 8 (Ag-N distances of $2.239(3)-2.373(3) \AA$ ), a sulphur atom of the bridging type with Ag-S distance of 2.5451(8) $\AA$ and finally, an oxygen atom belonging to a nitrate anion with Ag-O distance of 2.395(5) $\AA$. Again, the coordination geometry around the cation is a distorted tetrahedron (NAgN and SAgO angles of 99.64(12) and $119.31(17)^{\circ}$ respectively, NAgS angles of 94.12(8) and 132.81(9) ${ }^{\circ}$, and $\mathrm{NAgO}$ angles of $98.35(17)$ and $\left.108.99(16)^{\circ}\right)$.

The shortest distance between consecutive $\mathrm{Ag}^{+}$cations within the 1-D network is ca. $8.64 \AA$ for $7-\mathrm{AgSbF}_{6}$ and $7.38 \AA$ for $\mathbf{8}$ $\mathrm{AgNO}_{3}$.

For 7- $\mathrm{AgSbF}_{6}$, the 1D arrays are packed in parallel fashion along the [110] and [011] planes with $\mathrm{SbF}_{6}$ anions and $\mathrm{CHCl}_{3}$ solvent molecules lying between them. For $\mathbf{8}-\mathrm{AgNO}_{3}$, the $1 \mathrm{D}$ arrays are packed along the $a$ and $b$ axes, with water molecules lying between the chains.

The XRPD analysis of 7-AgSb 6 revealed a good match between simulated and observed patterns indicating the presence of a single microcrystalline phase (Figure 6). Unfortunately, 8$\mathrm{AgNO}_{3}$, probably due to loss of solvent molecules, was found to be unstable in air and thus the purity of the phase could not be established by XRPD.

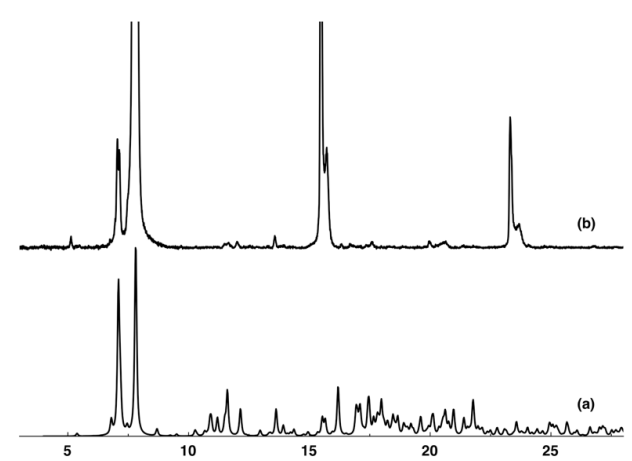

Figure 6: Comparison of PXRD patterns for $7-\mathrm{AgSbF}_{6}$ (a) simulated and powdered recorded (b).

\section{$2 D$ networks}

Two $2 \mathrm{D}$ coordination networks $\mathbf{6}-\mathrm{AgBF}_{4}$ and $\mathbf{8}-\mathrm{AgSbF}_{6}$ were obtained by combinations of tectons $\mathbf{6}$ and $\mathbf{8}$ with silver cation. In both cases, a 1/2 ligand/metal ratio is observed. Crystals are composed of cationic $2 \mathrm{D}$ networks, $\mathrm{BF}_{4}^{-}$and $\mathrm{SbF}_{6}{ }^{-}$anions in the case of tecton $\mathbf{6}$ and $\mathbf{8}$ respectively and solvent molecules $\left(\mathrm{H}_{2} \mathrm{O}\right.$ for $\mathbf{6}-\mathrm{AgBF} 4$ and $\mathrm{CHCl}_{3}$ for $\left.\mathbf{8}-\mathrm{AgSbF}_{6}\right)$.

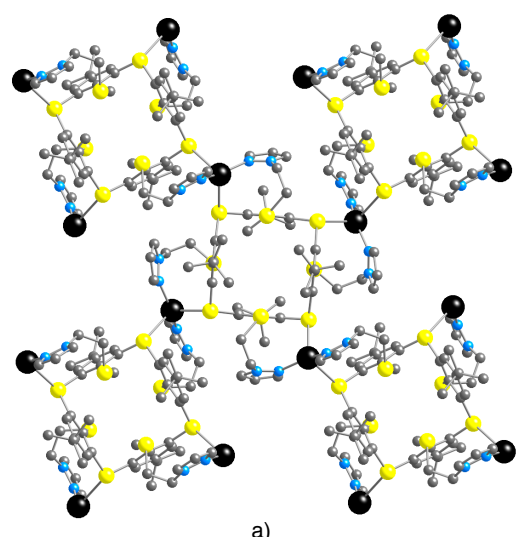

a)

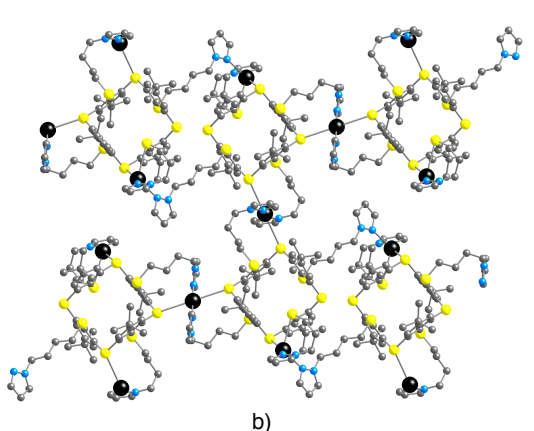

Figure 7: Portions of the solid state structures of $6-\mathrm{AgBF}_{4}(\mathrm{a})$ and $\mathbf{8}-\mathrm{AgSbF}_{6}$ (b) showing the mutual bridging between tectons 6 (a) and 8 (b) with silver cation leading to the formation of cationic 2-D coordination networks. Silver cations are presented with black spheres. $\mathrm{H}$ atoms, anions and solvent molecules are not presented for sake of clarity. For bond distances and angles see text. 
Whereas 6- $\mathrm{AgBF}_{4}$ crystallises in the tetragonal space group $I 41 / a, 8-\mathrm{AgSbF}_{6}$ crystallises in the triclinic $P-1$ space group. The cationic part of networks is generated by the interconnection of organic tectons $\mathbf{6}$ or $\mathbf{8}$ by silver cations (adopting either a triangular or a tetrahedral coordination geometry), through coordination bonds formed between the nitrogen donor atom of pyrazolyl moieties and sulphur atoms belonging to the macrocyclic backbone. In both cases, all four pyrazolyl groups take part in the binding of the cation and thus in the formation of the 2D networks (Figures 7). No specific interactions between silver atoms, anions or the organic tectons $\mathbf{6}$ or $\mathbf{8}$ with the solvent molecules were spotted in the crystal.

For the highly symmetrical 6-AgBF 4 2D network, the coordination sphere of silver cation is composed of two pyrazolyl nitrogen atoms belonging to two consecutive tectons 6 and two bridging sulphur atoms belonging to two adjacent macrocyclic moieties with Ag-N distances of 2.184(4) and 2.225(5) $\AA$ and Ag-S distances of 2.7758(13) and 2.8908(13) $\AA$. (Figure $7 \mathrm{a}$ ). The coordination geometry around the metal cation is a distorted tetrahedron (NAgN angle of $152.28(18)^{\circ}, \mathrm{SAgS}$ of 95.46(4) ${ }^{\circ}$ and NAgS angles varying between 86.31(13) and $\left.115.68(12)^{\circ}\right)$. Along the $c$ axis, the 2D networks are packed in parallel and staggered fashion preventing thus the formation of channels. $\mathrm{BF}_{4}^{-}$anions and water molecules are located between 2D networks.

For the 2D network 8-AgSbF6, three crystallographically independent silver cations are present within the network. They all display similar coordination environments composed of two pyrazolyl nitrogen atoms belonging to two different tectons $\mathbf{8}$ and two bridging sulphur atoms belonging to two adjacent macrocyclic moieties with Ag-N distances varying between 2.092(8) and 2.327(5) $\AA$ and Ag-S distances of 2.4503(13) and 3.257(8) $\AA$. Among the three crystallographically independent silver cations, one adopts a deformed tetrahedral coordination geometry (NAgN angle of $94.48(19)^{\circ}, \mathrm{SAgS}$ of $70.44(14)^{\circ}$ and NAgS angle ranging between $148.29(13)$ and $\left.115.68(12)^{\circ}\right)$. Both other two cations adopt a deformed square geometry (NAgN and SAgS angles of $180^{\circ}$ and NAgS angle of $75.29(11)^{\circ}, 79.64(12)^{\circ}, 100.35(12)$ and $\left.104.71(13)^{\circ}\right)$. The $2 \mathrm{D}$ networks are packed along the $a$ axis, and between the planes are located solvent molecules $\left(\mathrm{CHCl}_{3}\right.$ and $\left.\mathrm{H}_{2} \mathrm{O}\right)$ as well as the $\mathrm{SbF}_{6}{ }^{-}$counter anions.

Probably because of loss of solvent molecules, 6- $\mathrm{AgBF}_{4}$ and $\mathbf{8 -}$ $\mathrm{AgSbF}_{6}$ crystals are unfortunately not stable in air and the purity of solid batches could not be investigated by XRPD.

\section{D networks}

Interestingly combinations of the tecton $\mathbf{6}$ with three silver salts $\operatorname{AgXF}_{6}(\mathrm{X}=\mathrm{P}$, As and $\mathrm{Sb}$ ) lead to the formation of three isostructural 3D silver coordination networks $6-\mathrm{AgXF}_{6}(\mathrm{X}=\mathrm{P}$, As or $\mathrm{Sb}$ ). All three extended architectures crystallise in the tetragonal $I 41 / a$ space group with a $1 / 2$ metal/ligand ratio. The three 3D networks differ only by the nature of $\mathrm{X}$ in $\mathrm{XF}_{6}$ anion. Since all three crystals are isostructural, only $\mathbf{6}-\mathrm{AgPF}_{6}$ is described in detail below. However, metrics for the other two crystals $6-\mathrm{AgAsF}_{6}$ and $\mathbf{6}-\mathrm{AgSbF}_{6}$ are reported in table 2 . The overall structure of $\mathbf{6}-\mathrm{AgPF}_{6}$ is of pseudo-diamond type for which tecton $\mathbf{6}$ behaves as a tetrahedral connector (Figure 8a). The silver cation, adopting a deformed tetrahedral coordination geometry, acts as a two-connecting node each bridging two neighbour tectons 6 (Figures 8).

The surrounding around the silver cation is composed of two nitrogen atoms belonging to pyrazolyl units of different tectons 6 with Ag-N distance of 2.149(12) $\AA$ and two bridging sulphur atoms belonging to two different tectons 6 with $\mathrm{Ag}-\mathrm{S}$ distance of 3.040(3) $\AA$. The surrounding of the silver atom is a deformed tetrahedron with NAgN and SAgS angles of 170.1(8) and 129.2(7) ${ }^{\circ}$ respectively and NAgS angles of 87.1(5) and 97.2(6) The 3D pseudo diamond type architecture display channels (13 $\mathrm{x} 7 \AA$ ). The crystal contains two types of water molecules. Whereas as the first type are located between the macrocyclic units along the channel axis, the second type, forming $\mathrm{H}$ bonded dimers (O-O distance of 3.042(7) A) are within channels (Fig. 8b).

No interactions between the cationic network and the $\mathrm{XF}_{6}(\mathrm{X}=$ $\mathrm{P}$, As and $\mathrm{Sb}$ ) anions, occupying voids, could be spotted.

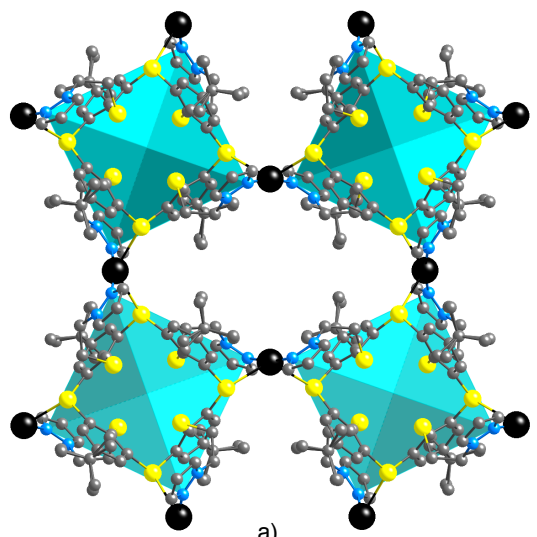

a)

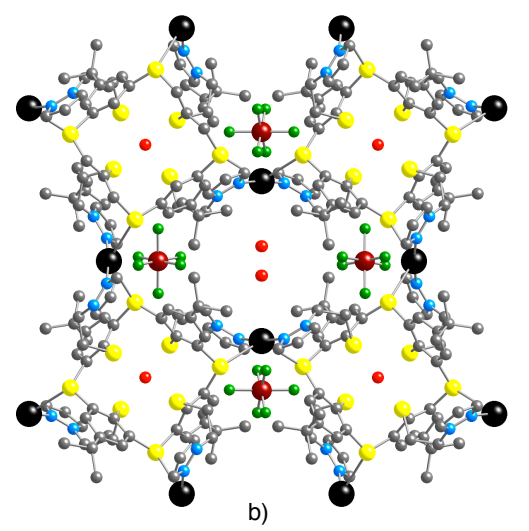

Figure 8: Portions of the solid state structures of 6-AgPF6 showing the mutual bridging between silver cations (black spheres) and tectons 6 leading to the formation of a cationic 3-D diamond-like coordination network ( $a$, polyhedral representation) and localizations of water molecules and anions (b). $\mathrm{H}$ atoms, anions and solvent molecules are not presented for sake of clarity. For bond distances and angles see text. 
Table 2: Selected bond distances and angles for compounds $6-\mathrm{AgXF}_{0}(\mathrm{X}=\mathrm{P}$, As and $\mathrm{Sb}$ ) extracted from the structural study by $\mathrm{X}$ ray diffraction on single crystals.

\begin{tabular}{|c|c|c|c|}
\hline & 6- $\mathrm{AgPF}_{6}$ & 6- $\mathrm{AgAsF}_{6}$ & 6- $\mathrm{AgSbF}_{6}$ \\
\hline $\mathrm{Ag}-\mathrm{N}(\AA)$ & $2.154(5)$ & $2.146(6)$ & $2.163(12)$ \\
\hline $\mathrm{Ag}-\mathrm{S}(\AA)$ & $3.066(3)$ & $3.067(4)$ & $3.015(4)$ \\
\hline $\mathrm{NAgN}\left({ }^{\circ}\right)$ & $173.3(3)$ & $173.9(3)$ & $165.3(6)$ \\
\hline $\mathrm{NAgS}\left({ }^{\circ}\right)$ & $87.5(5)$ & $87.5(5)$ & $85.7(7)$ \\
& $95.3(6)$ & $95.3(6)$ & $99.4(6)$ \\
\hline $\mathrm{SAgS}\left({ }^{\circ}\right)$ & $127.4(7)$ & $127.4(7)$ & $139.7(5)$ \\
\hline $\mathrm{O}-\mathrm{O}(\AA)$ & $3.042(7)$ & $2.876(7)$ & $3.143(7)$ \\
\hline
\end{tabular}

The XRPD analysis of microcrystalline samples of $\mathbf{6}-\mathrm{AgAsF}_{6}$ and $\mathbf{6}-\mathrm{AgSbF}_{6}$ revealed a good match between simulated and observed diagrams implying the presence of single crystalline phases (Figure 9). The XRPD diagram of $\mathbf{6}-\mathrm{AgPF}_{6}$ could not be recorded since the compound is not stable in air.

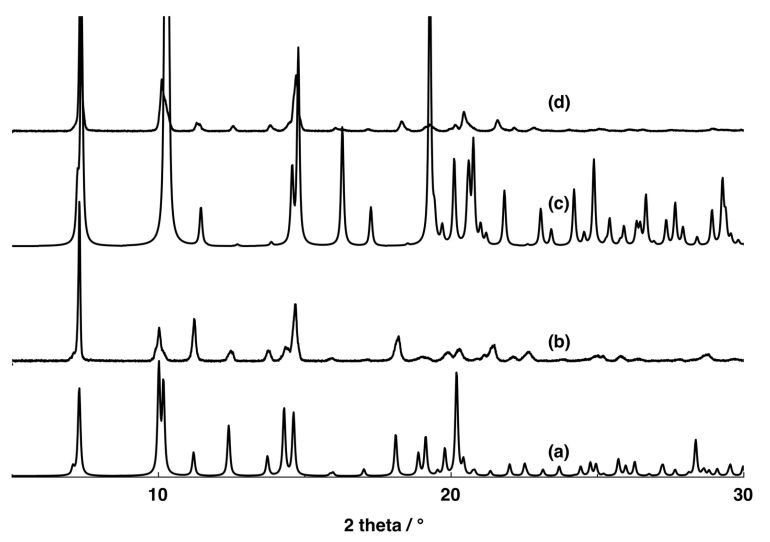

Figure 9: Comparison of XRPD patterns for (a) simulated for 6- $\mathrm{AgSbF}_{6}$ (b) recorded for $6-\mathrm{AgSbF}_{6}$ (c) simulated for $6-\mathrm{AgAsF}_{6}$ and (d) recorded for $6-\mathrm{AgAsF}_{6}$.

\section{Discussion}

Owing to the flexible nature of organic TCA and TMTCA, in 1,3- $A$ conformation, based tectons 3-8 and the presence, within their frameworks, of large number of potentially coordinating hetero atoms $(\mathrm{N}, \mathrm{O}$ and $\mathrm{S}$ for 3-5 and $\mathrm{N}$ and $\mathrm{S}$ for 6-8), the prediction of connectivity and geometry of coordination networks generated in the presence of silver cation as connecting metal is impossible. However, the nature of the extended architectures in the crystalline phase may be experimentally determined. The present contribution describes systematic investigations on combinations of 6 new tectons 3-8 and different silver salts $\left(\mathrm{NO}_{3}, \mathrm{BF}_{4}, \mathrm{XF}_{6}(\mathrm{X}=\mathrm{P}, \mathrm{As}\right.$ and $\mathrm{Sb})$ ). Under crystallization conditions used, no crystalline material could be obtained for combinations of tectons 3 and $\mathbf{4}$ with $\mathrm{Ag}^{+}$ cation. For the other tectons 5-8, 9 extended architectures of different connectivity and geometry have been obtained and characterized in the solid-state. In all cases, all four appended pyrazolyl coordinating groups participate in the binding of silver cation through Ag-N bonds.
In the case of tecton $\mathbf{5}$, independent of the nature of the counter ion $\left(\mathrm{BF}_{4}^{-}\right.$or $\left.\mathrm{SbF}_{6}^{-}\right)$, two $1 \mathrm{D}$ networks $\left(\mathbf{5}-\mathrm{AgSbF}_{6}\right.$ and $\left.5-\mathrm{AgBF}_{4}\right)$ with similar connectivity pattern ( $1 / 1$ metal/tecton ratio) have been obtained (Figure 10a). Bridging $\mathrm{S}$ atoms do not participate in the binding of silver cations and no specific interactions between anions and the framework were spotted.

The formation of 1D architectures has been also observed upon combining tectons $\mathbf{7}$ or $\mathbf{8}$ with silver cation $\left(\mathbf{7}-\mathrm{AgSbF}_{6}\right.$ and $\mathbf{8 -}$ $\mathrm{AgNO}_{3}$ ). However, for these two networks a $2 / 1$ metal/tecton ratio is observed (Figure 10b). In contrast with the above mentioned 1D networks obtained with tecton $\mathbf{5}$, for both tectons $\mathbf{7}$ and $\mathbf{8}, \mathrm{S}$ atoms bridging the thiophenol moieties take part in the binding of $\mathrm{Ag}^{+}$cation. In the case of $\mathbf{8}-\mathrm{AgNO}_{3}, \mathrm{NO}_{3}{ }^{-}$anions also bind $\mathrm{Ag}^{+}$cation through $\mathrm{Ag}-\mathrm{O}$ bonds.

In marked contrast, combinations of both tectons $\mathbf{6}$ and $\mathbf{8}$ with $\mathrm{Ag}^{+}$cation lead to the formation of similar 2D architectures (6$\mathrm{AgBF}_{4}$ and $8-\mathrm{AgSbF}_{6}$ ). Again, a $2 / 1$ metal/tecton ratio is observed (Figure 10c). Again as in the case of 7- $\mathrm{AgSbF}_{6}$ and $\mathbf{8 -}$ $\mathrm{AgNO}_{3}$ mentioned above, $\mathrm{S}$ atoms bridging the thiophenol moieties take part in the binding of $\mathrm{Ag}^{+}$cation.

Finally, in contrast with the $2 \mathrm{D}$ network obtained upon combining tecton 6 with $\mathrm{AgBF}_{4}$, its combinations with $\mathrm{AgXF}_{6}$ $(\mathrm{X}=\mathrm{P}, \mathrm{As}$ or $\mathrm{Sb})$ lead to the formation of porous isostructural crystals based on $3 \mathrm{D}$ networks $\left(6-\mathrm{AgXF}_{6}(\mathrm{X}=\mathrm{P}, \mathrm{As}\right.$ and $\left.\mathrm{Sb})\right)$ (Figure 10d). Interestingly, the formation of the pseudo diamond type architecture is independent of the nature of the octahedral anion. The porous crystals contain two types of water molecules with inclusion of $\mathrm{H}$-bonded dimers within the channels.

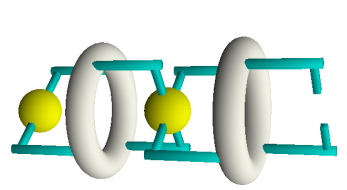

a)

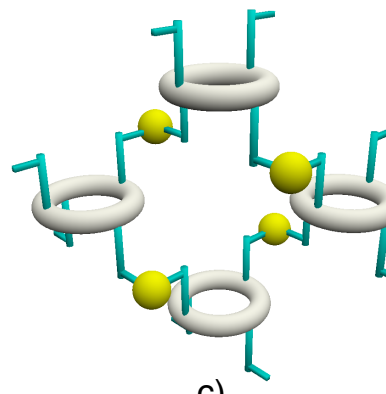

c)

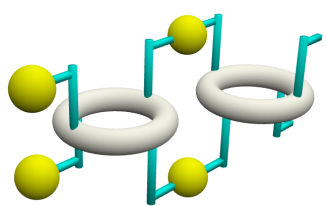

b)
Figure 10: Schematic representation of $1 \mathrm{D}$ networks 5- $\mathrm{AgBF}_{4}$ and $\mathbf{5}-\mathrm{AgSbF}_{6}$ obtained upon combining the organic tecton $\mathbf{5}$ with silver cation (a), 1D networks 7- $\mathrm{AgSbF}_{6}$ and $\mathbf{8}-\mathrm{AgNO}_{3}$ obtained upon combining the organic tectons $\mathbf{7}$ or $\mathbf{8}$ with silver cation (b), $2 \mathrm{D}$ networks $6-\mathrm{AgBF}_{4}$ and $8-\mathrm{AgSbF}_{6}$ obtained upon combining the organic tectons 6 or $\mathbf{8}$ with silver cation (c), 3D networks $\mathbf{6}-\mathrm{AgXF}_{n}(\mathrm{X}=\mathrm{P}, \mathrm{As}$ or $\mathrm{Sb}$ ) obtained upon combining the organic tectons $\mathbf{6}$ with silver cation (d). For sake of clarity only Ag--N interactions are represented.

Combinations of calix[4]arene in 1,3- $A$ conformation based tectons 3-8 with other metal cations are currently under investigation. 


\section{Acknowledgments}

We thank the Russian Scientific Foundation (grant $N^{\circ}$ 15-1330006) for financial support in synthesis and crystal preparation of some of the reported compounds. We thank the Tunisian Ministry of Education for scholarship of M.H.N. Financial supports from the University of Strasbourg, the International Centre for Frontier Research in Chemistry (icFRC), Laboratory of excellence LabEx CSC, Strasbourg, the Institut Universitaire de France, the CNRS are acknowledged.

Notes and references

a Kazan Federal University, Kremlevskaya str. 18, Kazan 420008, Russian Federation

${ }^{b}$ Molecular Tectonics Laboratory, UMR UdS-CNRS 7140, University of Strasbourg, Institut Le Bel, 4, rue Blaise Pascal, F-67000 Strasbourg, France.

${ }^{c}$ A. E. Arbuzov Institute of Organic and Physical Chemistry, Russian Academy of Science, Arbuzov str. 8, Kazan 420088, Russian Federation

${ }^{d}$ Université de Carthage, Laboratoire d'Application de la Chimie aux Ressources et Substances Naturelles et à l'Environnement (LACReSNE), unité des interactions moléculaires spécifiques, Faculté des Sciences de Bizerte, 7021 Bizerte, Tunisia

E-mail: ferlay@unistra.fr, hosseini@unistra.fr

[1] a) G. D. Desiraju, Crystal Engineering: The Design of Organic Solids, Elsevier, New York, 1989; b) C.B. Aakeroy and K.R. Seddon, Chem. Soc Rev., 1993, 22, 397; c) D. Braga, Angew. Chem., Int. Ed. 2004, 43, 2; d) Ö. Almarsson; M. J. Zaworotko, Chem. Commun. 2004, 1889; e) G. R. Desiraju; J. J.Vittal; A. Ramanan Crystal Engineering: A Text Book; World Scientific: Singapore; f) A. D. Bond CrystEngComm 2012, 14, 2363.

[2] Lehn, J.-M. Supramolecular Chemistry, Concepts and Perspectives, VCH, Weinheim, 1995.

[3] (a) J. D. Dunitz, Pure and Appl. Chem. 1991, 63, 177; (b) J. D. Dunitz, Chem. Commun., 2003, 545.

[4] a) S. Mann, Nature, 1993, 365, 499; b) M. Simard, D. Su, J. D. Wuest, J. Am. Chem. Soc., 1991, 113, 4696; c) M. W. Hosseini, Acc. Chem. Res. 2005, 38, 313.

[5] A. F. Wells, Three-dimensional Nets and Polyhedra, WileyInterscience, New York, 1977; Further Studies of Three-dimensional Nets, ACA Monograph No. 8, American Crystallographic Association, 1979.

[6] M. W. Hosseini, CrystEngComm., 2004, 6, 318.

[7 ] a) J. D. Wuest, Chem. Commun., 2005, 5830; b) M. W. Hosseini, Chem. Commun., 2005, 5825.

[8] (a) B. F. Abrahams, B. F. Hoskins, R. Robson, J. Am. Chem. Soc., 1991, 113, 3606; (b) S. R. Batten, R. Robson, Angew. Chem. Int. Ed., 1998, 37, 1460 .

[9] a) C. Kaes, M. W. Hosseini, NATO ASI Series, Ed. J. Viciana, 1998, C518, 53; b) M. W. Hosseini, NATO ASI Series, Ed. G. Tsoucaris,
1998, C519, 209; c) M. W. Hosseini, NATO ASI Series, Eds. D. Braga, G. Orpen, Serie c, 1999, C538, 181.

[10] (a) O. M. Yaghi, H. Li, C. Davis, D. Richardson, T. L. Groy, Acc. Chem. Res., 1998, 31, 474; (b) M. Eddaoudi, D. B. Moler, H. Li, B. Chen, T.M. Reineke, M. O'Keeffe, O. M. Yaghi, Acc. Chem. Res., 2001, 34, 319.

[11] (a) A. J. Blake, N. R. Champness, P. Hubberstey, W.-S. Li, M. A. Withersby, M. Schröder, Coord. Chem. Rev.,1999, 193, 117; (b) B. Moulton, M. J. Zaworotko, Chem. Rev., 2001, 101, 1629; (c) C. Janiak, Dalton Trans., 2003, 2781; (d) L. Carlucci, G. Ciani, D. M. Proserpio, Coord. Chem. Rev., 2003, 246, 247; (e) S. Kitagawa, R. Kitaura, S. Noro, Angew. Chem. Int. Ed., 2004, 43, 2334; (f) G. Férey, C. Mellot-Draznieks, C. Serre, F. Millange, Acc. Chem. Res., 2005, 38, 218; (g) D. Bradshaw, J. B. Claridge, E. J. Cussen, T. J. Prior, M. J. Rosseinsky, Acc. Chem. Res., 2005, 38, 273; (h) S. Kitagawa, K. Uemura, Chem. Soc. Rev. 2005, 34, 109; (i) D. Maspoch, D. Ruiz-Molina, J. Veciana, Chem. Soc. Rev. 2007, 36, 770; (j) J. R. Long, O. M. Yaghi, Chem. Soc. Rev., 2009, 38, 1213; (k) C. Janiak, J. L. Vieth, New J. Chem., 2010, 34, 2366; (1) Chem. Soc. Rev., 2009, 38, themed issue on metal-organic frameworks; (m) W. L. Leong, J. J. Vittal, Chem. Rev. 2011, 111, 688; (n) Chem. Rev., 2012, 112, Metal-Organic Frameworks special issue.

[12] (a) C.D. Gutsche in Calixarenes Revised: Monographs in Supramolecular Chemistry Vol. 6, The Royal Society of Chemistry, Cambridge, 1998; (b) Z. Asfari, V. Böhmer, J. Harrowfield, J. Vicens in Calixarenes 2001, (Eds. Z. Asfari, V. Böhmer, J. Harrowfield, J. Vicens) Kluwer Academic, Dordrecht, 2001.

[13] (a) H. Kumagai, M. Hasegawa, S. Miyanari, Y. Sugawa, Y. Sato, T. Hori, S. Ueda, H. Kamiyama, S. Miyano, Tetrahedron Lett., 1997, 38, 3971; (b) H. Akdas, L. Bringel, E. Graf, M. W. Hosseini, G. Mislin, J. Pansanel, A. De Cian, J. Fischer, Tetrahedron Lett., 1998, 39, 2311.

[14] (a) C. G. Gibbs, C. D. Gutsche, J. Am. Chem. Soc., 1993, 115, 5338; (b) C. G. Gibbs, P. K. Sujeeth, J. S. Rogers, G. G. Stanley, M. Krawiec, W. H. Watson, C. D. Gutsche, J Org. Chem., 1995, 60, 8394.

[15 X. Delaigue, J. McB. Harrowfield, M. W. Hosseini, A. De Cian, J. Fischer, N. Kyritsakas, Chem. Commun., 1994, 1579.

[16] P. Rao, M. W. Hosseini, A. De Cian, J. Fischer, Chem. Commun., 1999, 2169.

[17] M. W. Hosseini in Calixarenes 2001, (Eds. Z. Asfari, V. Böhmer, J. Harrowfield, J. Vicens) Kluwer Academic, Dordrecht, 2001, pp.110.

[18] (a) G. Mislin, E. Graf, M. W. Hosseini, A. Bilyk, A. K. Hall, J. M. Harrowfield, B. W. Skelton, A. H. White, Chem. Commun., 1999, 373; (b) H. Akdas, E. Graf, M. W. Hosseini, A. De Cian, A. Bilyk, B. W. Skelton, G. A. Koutsantonis, I. Murray, J. M. Harrowfield, A. H. White, Chem. Commun., 2002, 1042; (c) A. Bilyk, J. W. Dunlop, R. O. Fuller, A. K. Hall, J. M. Harrowfield, M. W. Hosseini, G. A. Koutsantonis, I. W. Murray, B. W. Skelton, A. N. Sobolev, R. L. Stamps, A. H. White, Eur. J. Inorg. Chem. 2010, 2127; (d) A. Bilyk, J. W. Dunlop, R. O. Fuller, A. K. Hall, J. M. Harrowfield, M. W. Hosseini, G. A. Koutsantonis, I. W. Murray, B. W. Skelton, R. L. Stamps, A. H. White, Eur. J. Inorg. Chem. 2010, 2106; (e) A. Bilyk, J. W. Dunlop, R. O. Fuller, A. K. Hall, J. M. Harrowfield, M. W. 
Hosseini, G. A. Koutsantonis, I. W. Murray, B. W. Skelton, A. N. Sobolev, R. L. Stamps, A. H. White Eur. J. Inorg. Chem. 2010, 2106; (f) A. Gehin, S. Ferlay, J. M. Harrowfield, D. Fenske, N. Kyritsakas and M. W. Hosseini, Inorg. Chem., 2012, 51, 5481.

[19] (a) T. Kajiwara, N. Kon, S. Yokozawa, T. Ito, N. Iki, S. Miyano, J. Am. Chem. Soc. 2002, 124, 11274; (b) C. Desroches, G. Pilet, S. A. Borsch, S. Parola, D. Luneau, Inorg. Chem. 2005, 44, 9112; (c) Y. F. Bi, X. T. Wang, W. P. Liao, X. W. Wang, R. P. Deng, H. J. Zhang, S. Gao, Inorg. Chem. 2009, 48, 11743; (d) Y. Bi, X-T. Wang, W. Liao, X. Wang, X. Wang, H. Zhang, S. Gao, J. Am. Chem. Soc. 2009, 131, 11650 .

[20] T. Kajiwara, N. Iki, M.Yamashita, Coord. Chem. Rev. 2007, 251, 1734.

[21] M. N. Kozlova, S. Ferlay, S. E. Solovieva, I. S. Antipin, A. I. Konovalov, N. Kyritsakas, M. W. Hosseini, Dalton Trans., 2007, 5126.

[22] H. Akdas, E. Graf, M. W. Hosseini, A. De Cian, J. M. Harrowfield, Chem. Commun., 2000, 2219.

[23] M. N. K Kozlova, S. Ferlay, N. Kyritsakas, M. W. Hosseini, S. E. Solovieva, I. S. Antipin, A. I. Konovalov, Chem. Commun., 2009, 2514.

[24] J. Sykora, M. Himl, I. Stobor, I. Cisarova, P. Lhotak, Tetrahedron, 2007, 63, 2244.

[25] Y. Bi, W. Liao, X. Wang, R. Deng and H. Zhang, Eur. J. Inorg. Chem., 2009, 4989.

[26] (a) K. Kim, S. Park, K-M. Park and S. S. Lee, Cryst. Growth Des., 2011, 11, 4059; (b) M. Liu and W. Liao, Chem. Commun., 2012, 5727.

[27] (a) K. Hirata, T. Suzuki, A. Noya, I. Takei, M. Hidai, Chem. Commun. 2005, 3718 ; (b) D. Buccella, G. Parkin, Chem. Commun. 2009, 289.

[28] a) A. Ovsyannikov, S. Ferlay, S. E. Solovieva, I. S. Antipin, A. I. Konovalov, N. Kyritsakas, M. W. Hosseini, Inorg. Chem., 2013, 52,
6776 ; b) A. Ovsyannikov, S. Ferlay, S. E. Solovie Konovalov, N. Kyritsakas, M. W. Hosseini, Dalton [29] a) A. Ovsyannikov, M. N. Lang, S. Ferlay, S Antipin, A. I. Konovalov, N. Kyritsakas, M. Trans., 2013, 42, 116; b) A. Ovsyannikov, S. Fe I. S. Antipin, A. I. Konovalov, N. Kyritsaka Dalton Trans., 2014, 43, 158; c) A. Ovsyanni Solovieva, I. S. Antipin, A. I. Konovalov, N Hosseini CrystEngComm, 2014, 3765.

[30] A. Ovsyannikov, S. Ferlay, S. E. Solovieva, Konovalov, N. Kyritsakas, M. W. Hosseini, 2014, accepted, rus. Известия Академии Наук ISSN 0002-3353, 2015, 8, 1955-1962.

[31] N. Iki, C. Kabuto, T. Fukushima, H. Kum Miyanari, T. Miyashib and S. Miyanoa, Tetrahed

[32] C. Blaszykowski, E. Aktoudianakis, C. Bressy Lautens, Org. Lett., 2006, 8, 2043.

[33] I. Bitter, V. Csokai, Tetrahedron Lett., 2003, 44

[34] H. Akdas, L. Bringel, V. Bulach, E. Graf, M. Cian, Tetrahedron Letters, 2002, 43, 8975.

[35] G. M. Sheldrick, Program for Crystal Structure of Göttingen, Göttingen, Germany, 1997.

[36] a) K. Paek, J. Yoon and Y. Suh, J. Chem. S 2001, 916; b) R. Zadmard, M. Junkers, T. Schra Kraft, J. Org. Chem. 2003, 68, 6511.

[37] a) J. Ehrhart, J-M. Planeix, N. Kyritsakas-Gru Dalton Trans., 2009, 6309; b) J. Ehrhart, Kyritsakas-Gruber, M. W. Hosseini, Dalton Tra Ehrhart, J-M. Planeix, N. Kyritsakas-Gruber, M. Trans., 2010, 2137.

[38] a) C. Klein, E. Graf, M. W. Hosseini, A. De Chem. Commun., 2000, 239; b) G. Laugel, E. C J.-M. Planeix and N. Kyritsakas, New J. Chem., 


\section{Journal Name}

\section{ARTICLE}

Table 1: Crystallographic data for structural analyses of $\mathbf{3}$ and $\mathbf{6}$

\begin{tabular}{|c|c|c|}
\hline Formula & $\begin{array}{c}\mathbf{3} \\
\mathrm{C}_{60} \mathrm{H}_{72} \mathrm{~N}_{8} \mathrm{O}_{4} \mathrm{~S}_{4}, \mathrm{H}_{2} \mathrm{O} \\
\end{array}$ & $\begin{array}{c}\mathbf{6} \\
\mathrm{C}_{60} \mathrm{H}_{72} \mathrm{~N}_{8} \mathrm{~S}_{8} \\
\end{array}$ \\
\hline Molecular weight & 1115.51 & 1161.73 \\
\hline Crystal system & monoclinic & monoclinic \\
\hline Space group & $\mathrm{P} 2(1) / \mathrm{c}$ & $\mathrm{C} 12 / \mathrm{c} 1$ \\
\hline $\mathrm{a}(\AA)$ & $15.2164(12)$ & $26.6378(6)$ \\
\hline $\mathrm{b}(\AA)$ & $13.1809(10)$ & $12.7707(3)$ \\
\hline $\mathrm{c}(\AA)$ & $29.309(2)$ & $19.6019(4)$ \\
\hline$\alpha(\operatorname{deg})$ & 90 & 90 \\
\hline$\beta(\operatorname{deg})$ & $92.577(3)$ & $115.0020(10)$ \\
\hline$\gamma(\operatorname{deg})$ & 90 & 90 \\
\hline $\mathrm{V}\left(\AA^{3}\right)$ & $5872.5(8)$ & $6043.4(2)$ \\
\hline Z & 4 & 4 \\
\hline Colour & Colourless & Colourless \\
\hline Crystal $\operatorname{dim}\left(\mathrm{mm}^{3}\right)$ & $0.06 \times 0.06 \times 0.05$ & $0.040 \times 0.050 \times 0.050$ \\
\hline Dcalc $\left(\mathrm{gcm}^{-3}\right)$ & 1.262 & 1.277 \\
\hline $\mathrm{F}(000)$ & 2376 & 2464 \\
\hline$\mu(\mathrm{mm}-1)$ & 0.217 & 0.341 \\
\hline Wavelength $(\AA)$ & 0.71073 & 0.71073 \\
\hline Number of data meas. & 41169 & 20696 \\
\hline Number of data with $\mathrm{I}>2 \sigma(\mathrm{I})$ & $16909[\mathrm{R}(\mathrm{int})=0.0427]$ & $7884[\mathrm{R}(\mathrm{int})=0.0235]$ \\
\hline $\mathrm{R}$ & $\mathrm{R} 1=0.1114, \mathrm{wR} 2=0.2497$ & $\mathrm{R} 1=0.0479, \mathrm{wR} 2=0.1393$ \\
\hline $\mathrm{Rw}$ & $\mathrm{R} 1=0.1732, \mathrm{wR} 2=0.2668$ & $\mathrm{R} 1=0.0680, \mathrm{wR} 2=0.1568$ \\
\hline GOF & 1.124 & 1.004 \\
\hline Largest peak in final difference $\left(\mathrm{e} \AA^{-3}\right)$ & 1.069 and -0.689 & 0.732 and -0.720 \\
\hline
\end{tabular}

${ }^{\mathrm{a}} R=\Sigma\left(|| F_{\mathrm{o}}|-| F_{\mathrm{c}}||\right) / \Sigma\left|F_{\mathrm{o}}\right| ;{ }^{b} w R=\left[\Sigma\left[w\left(F_{\mathrm{o}}{ }^{2}-F_{\mathrm{c}}{ }^{2}\right)^{2}\right] / \Sigma w\left(F_{\mathrm{o}}{ }^{2}\right)^{2}\right]^{1 / 2}$ 


\section{Journal Name}

\section{RSCPublishing}

\section{COMMUNICATION}

\begin{tabular}{|c|c|c|c|c|c|c|c|}
\hline Formula & $\begin{array}{c}\text { 5-AgSbF } \\
\mathrm{C}_{68} \mathrm{H}_{88} \mathrm{~N}_{8} \mathrm{O}_{4} \mathrm{~S}_{4} \\
\mathrm{AgSbF}_{6}, \mathrm{CHCl}_{3}\end{array}$ & 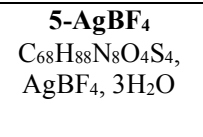 & 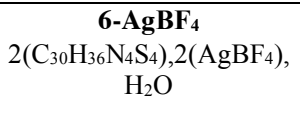 & $\begin{array}{c}\text { 6- } \mathbf{A g P F}_{6} \\
\mathrm{C}_{30} \mathrm{H}_{36} \mathrm{~N}_{4} \mathrm{~S}_{4} \\
\mathrm{AgPF}_{6}, 3 \mathrm{H}_{2} \mathrm{O}\end{array}$ & $\begin{array}{c}\text { 6-AgSbF } \\
\mathrm{C}_{30} \mathrm{H}_{36} \mathrm{~N}_{4} \mathrm{~S}_{4} \\
\mathrm{AgSbF}_{6}, 3 \mathrm{H}_{2} \mathrm{O}\end{array}$ & $\begin{array}{c}\text { 6-AgAsF } \\
\mathrm{C}_{30} \mathrm{H}_{36} \mathrm{~N}_{4} \mathrm{~S}_{4} \\
\mathrm{AgAsF}_{6}, 3 \mathrm{H}_{2} \mathrm{O}\end{array}$ & $\begin{array}{c}\text { 7-AgSbF } \\
\mathrm{C}_{64} \mathrm{H}_{80} \mathrm{~N}_{8} \mathrm{~S}_{8}, \\
\left(\mathrm{AgSbF}_{6}\right)_{2}, 2 \\
\mathrm{CHCl}_{3}\end{array}$ \\
\hline $\begin{array}{c}\text { Molecular } \\
\text { weight }\end{array}$ & 1672.69 & 1458.43 & 1569.11 & 887.75 & 978.53 & 931.70 & 2143.82 \\
\hline Crystal system & monoclinic & monoclinic & tetragonal & tetragonal & tetragonal & tetragonal & triclinic \\
\hline $\mathrm{a}(\AA)$ & $16.8948(3)$ & $22.7969(11)$ & $16.0983(5)$ & $24.2538(9)$ & $24.958(3)$ & $24.4165(8)$ & $15.6888(4)$ \\
\hline $\mathrm{b}(\AA)$ & $14.6737(3)$ & $17.2741(8)$ & $16.0983(5)$ & $24.2538(9)$ & $24.958(3)$ & $24.4165(8)$ & $17.4322(5)$ \\
\hline $\mathrm{c}(\AA)$ & $30.1055(6)$ & $19.4952(9)$ & $54.7728(15)$ & $13.6809(5)$ & $13.8496(19)$ & $13.7457(4)$ & $17.6605(5)$ \\
\hline$\alpha(\operatorname{deg})$ & 90 & 90 & 90 & 90 & 90 & 90 & $80.5980(10)$ \\
\hline$\beta(\operatorname{deg})$ & $90.7060(10)$ & $103.7860(9)$ & 90 & 90 & 90 & 90 & $76.5880(10)$ \\
\hline$\gamma(\operatorname{deg})$ & 90 & 90 & 90 & 90 & 90 & 90 & $71.0250(10)$ \\
\hline $\mathrm{V}\left(\AA^{3}\right)$ & $7462.9(3)$ & $7456.0(6)$ & $14194.7(10)$ & $8047.7(7)$ & $8627 .(2)$ & $8194.7(6)$ & $4422.6(2)$ \\
\hline Colour & Colourless & Colourless & Colourless & Colourless & Colourless & Colourless & Colourless \\
\hline $\begin{array}{l}\text { Crystal dim } \\
\left(\mathrm{mm}^{3}\right)\end{array}$ & $\begin{array}{c}0.07 \times 0.06 \times \\
0.06 \\
\end{array}$ & & $0.050 \times 0.050 \times 0.060$ & $\begin{array}{c}0.060 \times 0.060 \times \\
0.070\end{array}$ & $\begin{array}{c}0.060 \times 0.060 \times \\
0.070\end{array}$ & $\begin{array}{c}0.050 \times 0.050 \times \\
0.060\end{array}$ & $\begin{array}{c}0.08 \times 0.06 \times \\
0.06 \\
\end{array}$ \\
\hline Dcalc $\left(\mathrm{gcm}^{-3}\right)$ & 1.489 & 1.299 & 1.468 & 1.465 & 1.507 & 1.510 & 1.610 \\
\hline $\mathrm{F}(000)$ & 3432 & 3064 & 6416 & 3632 & 3920 & 3776 & 2136 \\
\hline$\mu(\mathrm{mm}-1)$ & 0.910 & 0.447 & 0.853 & 0.811 & 1.332 & 1.558 & 1.477 \\
\hline Wavelength $(\AA)$ & 0.71073 & 0.71073 & 0.71073 & 0.71073 & 0.71073 & 0.71073 & 0.71073 \\
\hline $\begin{array}{c}\text { Number of data } \\
\text { meas. }\end{array}$ & 247880 & 32679 & 116099 & 104738 & 22682 & 97274 & 176449 \\
\hline $\begin{array}{l}\text { Number of data } \\
\text { with } I>2 \sigma(I)\end{array}$ & $\begin{array}{c}23255[\mathrm{R}(\mathrm{int}) \\
=0.0454]\end{array}$ & $\begin{array}{c}20781[\mathrm{R}(\mathrm{int})= \\
0.0340]\end{array}$ & $10377[\mathrm{R}(\mathrm{int})=0.0894]$ & $\begin{array}{c}5185[\mathrm{R}(\mathrm{int})= \\
0.0318]\end{array}$ & $\begin{array}{c}6216[\mathrm{R}(\mathrm{int})= \\
0.0557]\end{array}$ & $\begin{array}{c}6060[\mathrm{R}(\mathrm{int})= \\
0.0304]\end{array}$ & $\begin{array}{c}23624[\mathrm{R}(\mathrm{int})= \\
0.0365]\end{array}$ \\
\hline $\mathrm{R}$ & $\begin{array}{c}\mathrm{R} 1=0.0591, \\
\mathrm{wR} 2=0.1543\end{array}$ & $\begin{array}{c}\mathrm{R} 1=0.0829, \\
\mathrm{wR} 2=0.2117\end{array}$ & $\begin{array}{c}\mathrm{R} 1=0.0796, \mathrm{wR} 2= \\
0.2152\end{array}$ & $\begin{array}{c}\mathrm{R} 1=0.0495, \\
\mathrm{wR} 2=0.1563\end{array}$ & $\begin{array}{c}\mathrm{R} 1=0.1092, \\
\mathrm{wR} 2=0.3064\end{array}$ & $\begin{array}{c}\mathrm{R} 1=0.0485, \\
\mathrm{wR} 2=0.1444\end{array}$ & $\begin{array}{c}\mathrm{R} 1=0.0646, \\
\mathrm{wR} 2=0.1905\end{array}$ \\
\hline $\mathrm{Rw}$ & $\begin{array}{c}\mathrm{R} 1=0.0806, \\
\mathrm{wR} 2=0.1704\end{array}$ & $\begin{array}{c}\mathrm{R} 1=0.1232, \\
\mathrm{wR} 2=0.2471\end{array}$ & $\begin{array}{c}\mathrm{R} 1=0.1221, \mathrm{wR} 2= \\
0.2376\end{array}$ & $\begin{array}{c}\mathrm{R} 1=0.0535, \\
\mathrm{wR} 2=0.1644\end{array}$ & $\begin{array}{c}\mathrm{R} 1=0.1457, \\
\mathrm{wR} 2=0.3320\end{array}$ & $\begin{array}{c}\mathrm{R} 1=0.0602, \\
\mathrm{wR} 2=0.1516\end{array}$ & $\begin{array}{c}\mathrm{R} 1=0.0973, \\
\mathrm{wR} 2=0.2215\end{array}$ \\
\hline $\begin{array}{l}\text { Largest peak in } \\
\text { final difference } \\
\qquad\left(\mathrm{e} \AA^{-3}\right)\end{array}$ & $\begin{array}{l}4.498 \text { and - } \\
2.745\end{array}$ & 2.163 and -0.799 & 2.347 and -2.478 & 1.445 and -0.457 & 1.985 and -1.355 & 1.316 and -0.838 & 1.941 and -1.804 \\
\hline
\end{tabular}

